\title{
OPEN The optimal alternative for quantifying reference evapotranspiration in climatic sub-regions of Bangladesh
}

\author{
Roquia Salam¹, Abu Reza Md. Towfiqul Islam¹, Quoc Bao Pham²,3, Majid Dehghani", \\ Nadhir Al-Ansari ${ }^{5}$ \& Nguyen Thi Thuy Linh ${ }^{6,7 凶}$
}

Reference evapotranspiration $\left(E T_{0}\right.$ ) is a basic element for hydrological designing and agricultural water resources management. The FAO56 recommended Penman-Monteith (FAO56-PM) formula recognized worldwide as the robust and standard model for calculating $\mathrm{ET}_{0}$. However, the use of the FAO56-PM model is restricted in some data-scarce regions like Bangladesh. Therefore, it is imperative to find an optimal alternative for estimating ET。against FAO56-PM model. This study comprehensively compared the performance of 13 empirical models (Hargreaves-Samani, HargreavesM1, Hargreaves M2, Berti, WMO, Abtew, Irmak 1, Irmak 2, Makkink, Priestley-Taylor, Jensen-Haise, Tabari and Turc) by using statistical criteria for 38-years dataset from 1980 to 2017 in Bangladesh. The radiation-based model proposed by Abtew $\left(\mathrm{ET}_{0,6}\right)$ was selected as an optimal alternative in all the sub-regions and whole Bangladesh against FAO56-PM model owing to its high accuracy, reliability in outlining substantial spatiotemporal variations of $\mathrm{ET}_{\mathrm{o}}$, with very well linearly correlation with the FAO56-PM and the least errors. The importance degree analysis of 13 models based on the random forest (RF) also depicted that $A b t e w\left(E T_{0,6}\right)$ is the most reliable and robust model for $\mathrm{ET}_{\mathrm{o}}$ computation in different sub-regions. Validation of the optimal alternative produced the largest correlation coefficient of 0.989 between $\mathrm{ET}_{0,5}$ and $\mathrm{ET}_{0,6}$ and confirmed that $A$ btew $\left(\mathrm{ET}_{0,6}\right)$ is the best suitable method for $\mathrm{ET}_{\mathrm{o}}$ calculation in Bangladesh.

Evapotranspiration (ET) is a physical aerodynamics process in which water moves from liquid to gaseous stage, whereas bringing from the soil to the atmospheric surface ${ }^{1}$. It denotes to both evaporation from vegetation and soil fields and transpiration from plants. Two distinct processes (evaporation and transpiration) happen concurrently, and there is no alternative way of differentiating one from the other. ET is one of the basic elements of the water cycle, and its estimation is necessary to drought mitigation and management as well as other fields, including agro-meteorology, hydrology, climatology, and environmental studies ${ }^{2-5}$. For this reason, many drought indices such as Reconnaissance Drought Index (RDI) ${ }^{6}$, Standardized Precipitation Evapotranspiration Index $(\mathrm{SPEI})^{7}$, and the Water Surplus Variability Index (WSVI $)^{8}$ are based on the ET. Besides, two closely associated terms and concepts are potential evapotranspiration (ETp) and reference evapotranspiration $\left(\mathrm{ET}_{\mathrm{o}}\right)$ that estimate the atmospheric evaporation demand. ETp is defined as the rate of water transpired in a specific time by a crop, fully shading the ground, of constant height with adequate soil water setting in the outline $\mathrm{e}^{9,10}$. On the other hand, $\mathrm{ET}_{\mathrm{o}}$ is expressed as the ET rate from a reference crop surface, where the reference crop surface is a theoretical grass or alfalfa with accurate and recognized characteristics ${ }^{1,11}$. However, the definition of $\mathrm{ET}_{\mathrm{o}}$ is more precise and specific than the ETp. The application of the terms ETp and $\mathrm{ET}_{\mathrm{o}}$ have been puzzled for several decades. One ideal example is that Hargreaves and Samani ${ }^{12}$ used the term "ETp" whereas again Hargreaves and Samani ${ }^{13}$ applied the term " $\mathrm{ET}_{\mathrm{o}}$. Under the well-known background of global warming in recent decades, the term $\mathrm{ET}_{\mathrm{o}}$ has been

\footnotetext{
${ }^{1}$ Department of Disaster Management, Begum Rokeya University, Rangpur 5400, Bangladesh. ${ }^{2}$ Environmental Quality, Atmospheric Science and Climate Change Research Group, Ton Duc Thang University, Ho Chi Minh City, Vietnam. ${ }^{3}$ Faculty of Environment and Labour Safety, Ton Duc Thang University, Ho Chi Minh City, Vietnam. ${ }^{4}$ Civil Engineering Department, Vali-e-Asr University of Rafsanjan, Rafsanjan, Iran. ${ }^{5}$ Department of Civil, Environmental and Natural Resources Engineering, Lulea University of Technology, 97187 Lulea, Sweden. ${ }^{6}$ Institute of Research and Development, Duy Tan University, Danang 550000, Vietnam. ${ }^{7}$ Faculty of Environmental and Chemical Engineering, Duy Tan University, Danang 550000, Vietnam. ${ }^{\bowtie}$ email: nguyentthuylinh58@duytan.edu.vn
} 
broadly applied in hydrology ${ }^{14-16}$, agronomy field ${ }^{17-19}$, irrigation engineering ${ }^{4,20,21}$ and meteorological field ${ }^{22,23}$. The application of $\mathrm{ET}_{\mathrm{o}}$ is also used in the studies of crop water demand. Therefore, knowledge of $\mathrm{ET}_{\mathrm{o}}$ is of great importance in agricultural water management, hydrological field, climate change, and irrigation practice ${ }^{24,25}$.

FAO recommended Penman-Monteith (FAO56-PM) method is the sole standard method for estimating $\mathrm{ET}_{\mathrm{o}}^{1,20,26}$. The main limitation of the FAO56-PM method is the difficulty in obtaining all necessary input data (air temperature, humidity, solar radiation, and wind speed). In such circumstances, simple equations or alternative methods are often used to estimate $\mathrm{ET}_{\mathrm{o}}{ }^{27}$. The major advantages of an optimal empirical method are the simplicity, low cost, ease of application, and easy access to a few climatic input data measured in most of meteorological stations ${ }^{28}$. Thus, an optimal empirical model is vital for $\mathrm{ET}_{\mathrm{o}}$ estimation in data-limited regions across the globe, including Bangladesh.

The selection of an optimal empirical model for calculating the $\mathrm{ET}_{\mathrm{o}}$ is significant for agricultural water resources management, hydrological planning and irrigation designing ${ }^{11,24,29}$. In recent decades, a large number of empirical models have been developed to estimate the $\mathrm{ET}_{0}$, which have been widely reported in the literature (Table S1). These empirical models can be demarcated into five types mainly based on the data requirement: mass transfer-based ${ }^{30,31}$, temperature-based ${ }^{11}$, radiation-based ${ }^{13,32-36}$, combined-based ${ }^{24,33-35}$ and the pan evaporation-based models ${ }^{37-39}$ (Table S1). Earlier studies showed that the performance of various empirical models exhibited spatiotemporal variations, and most of these empirical models might be region-specific that enhanced the uncertainty problem in the identified spatiotemporal patterns. To solve this issue, local adjustment and validation of empirical models are required against the standard FAO56-PM model at various regions with various climatic contexts for accurate estimation of the $\mathrm{ET}_{\mathrm{o}}{ }^{24}$. Most of the previous studies revealed that the performance of empirical models for estimating $\mathrm{ET}_{\mathrm{o}}$ showed significant regional differences ${ }^{40,41}$. For instance, the calibrated adjusted Hargreaves model performed better than the calibrated Priestley-Taylor model for measuring $\mathrm{ET}_{\mathrm{o}}$ in Serbia ${ }^{42}$. Quej et al. $^{43}$ assessed the performance of the temperature-based $\mathrm{ET}_{\mathrm{o}}$ models and found that the Hargreaves-Samani model exhibited the best performance in a tropical sub-humid climate. Krishna ${ }^{44}$ pointed out that the Turc model was an optimal alternative for the estimation of the $\mathrm{ET}_{\mathrm{o}}$ under a humid subtropical climate, India. Li et al. ${ }^{24}$ reported that combination-based Valiantzas 3 was the best model for estimating $\mathrm{ET}_{\mathrm{o}}$ in the humid to sub-humid region, China. On the contrary, Pandey and Pandey ${ }^{45}$ found that the Hargreaves-Samani method had a larger overestimation than the standard FAO56-PM in humid areas of India. These contrasting outcomes can be attributed to variations in regional climate, and geography. However, whether empirical models influence the computation procedure of the $\mathrm{ET}_{\mathrm{o}}$ against the $\mathrm{FAO} 56-\mathrm{PM}$ model remains uncertain. Therefore, it is crucial to conduct research appraising the performance of the empirical models in Bangladesh to determine an optimal alternative to $\mathrm{ET}_{\mathrm{o}}$ and their changes shifted overtimes at the regional scale and differ spatially ${ }^{14,15}$.

Bangladesh, the vast deltaic plain, a low-lying subtropical humid climatic country, is positioned in Southeast Asia, has a total land area of 147,700 square $\mathrm{km}^{46}$ (Supplementary Figure S1). The country has a complex geomorphic setting and complicated hydrologic system which comprises various water bodies, wetlands, floodplain, flood basins, agricultural land, forest, and hilly regions. The elevations of most regions of the country varied from 1 to $60 \mathrm{~m}$ above the mean sea level, which forms generally low-lying areas from the east to the west, making a so-called "delta-shaped" landform ${ }^{4}$. Nevertheless, Bangladesh is not only faced this type of difficulty in obtaining long-term and complete climatic datasets but also this poor country experiences similar phenomena owing to naturals such as a complicated hydro-geographic and climatic setting and humankind e.g., low economic growth, lack of proper knowledge and technological hindering causes. Under this circumstance, for the $\mathrm{ET}_{\mathrm{o}}$ appraisal of Bangladesh, an alternative empirical model depending on the limited climatic dataset is needed ${ }^{47}$. Therefore, it is of paramount importance to validate an appropriate alternative model which is easier in calculation procedure with fewer climatic variable requirements and good precision in comparison with the FAO56-PM model in various climatic sub-regions of Bangladesh. To the author's knowledge, so far, a systematic and thorough investigation for choosing an optimal alternative for estimating $\mathrm{ET}_{\mathrm{o}}$ has not been conducted in Bangladesh till now, particularly at a monthly and regional scale, which in itself is the novelty of this study.

Based on the aforementioned research gaps, in this research, 13 widely employed empirical models selected for performance evaluation, including four temperature-based model (Hargreaves-Samani, Hargreaves M1, Hargreaves M2, and Berti), one mass transfer-based models (WMO) and eight radiation-based models (Makkink, Priestly-Taylor, Jensen-Haise, Abtew, Irmak1, Irmak 2, Turc, and Tabari), based on the extensive literature review of meteorological variables, climatic regional differences, and their universal applicability. Subsequently, this study seeks three hypotheses: first, the various empirical models will generate considerably various outcomes for estimating the $\mathrm{ET}_{\mathrm{o}}$ at a monthly and regional scale; second, identifying the importance degree of empirical models that can indicate which model is outperformed against the FAO56-PM model at the regional scale and third, the simple linear regression can efficiently validate the 13 models against the FAO56-PM model in different sub-regions and whole Bangladesh. The specific objectives of this study are: (1) to analyze the spatiotemporal changes and the trends of $\mathrm{ET}_{\mathrm{o}}$ in Bangladesh for the period of 1980-2017 at a monthly scale, (2) to compare the performances of 13 empirical models against the FAO56-PM model for $\mathrm{ET}_{\mathrm{o}}$ estimation in climatic sub-regions of Bangladesh, (3) to choose an optimal alternative of the FAO56-PM ET $\mathrm{F}_{\mathrm{o}}$ model, which will be easier in $\mathrm{ET}_{\mathrm{o}}$ quantification and apply few meteorological variables, (4) to identify the most outperformed empirical model against FAO56-PM model using the heuristic random forest method, and (5) to validate 13 empirical models using linear regression to opt an alternative empirical model against FAO56-PM model. The novelty of this research lies in employing 13 empirical models with a heuristic random forest model for the first time in Bangladesh that enables us to find an optimal alternative used for important environmental implication from the most reliable and outperformed equations for $\mathrm{ET}_{\mathrm{o}}$ computation in different climatic sub-regions of Bangladesh. 


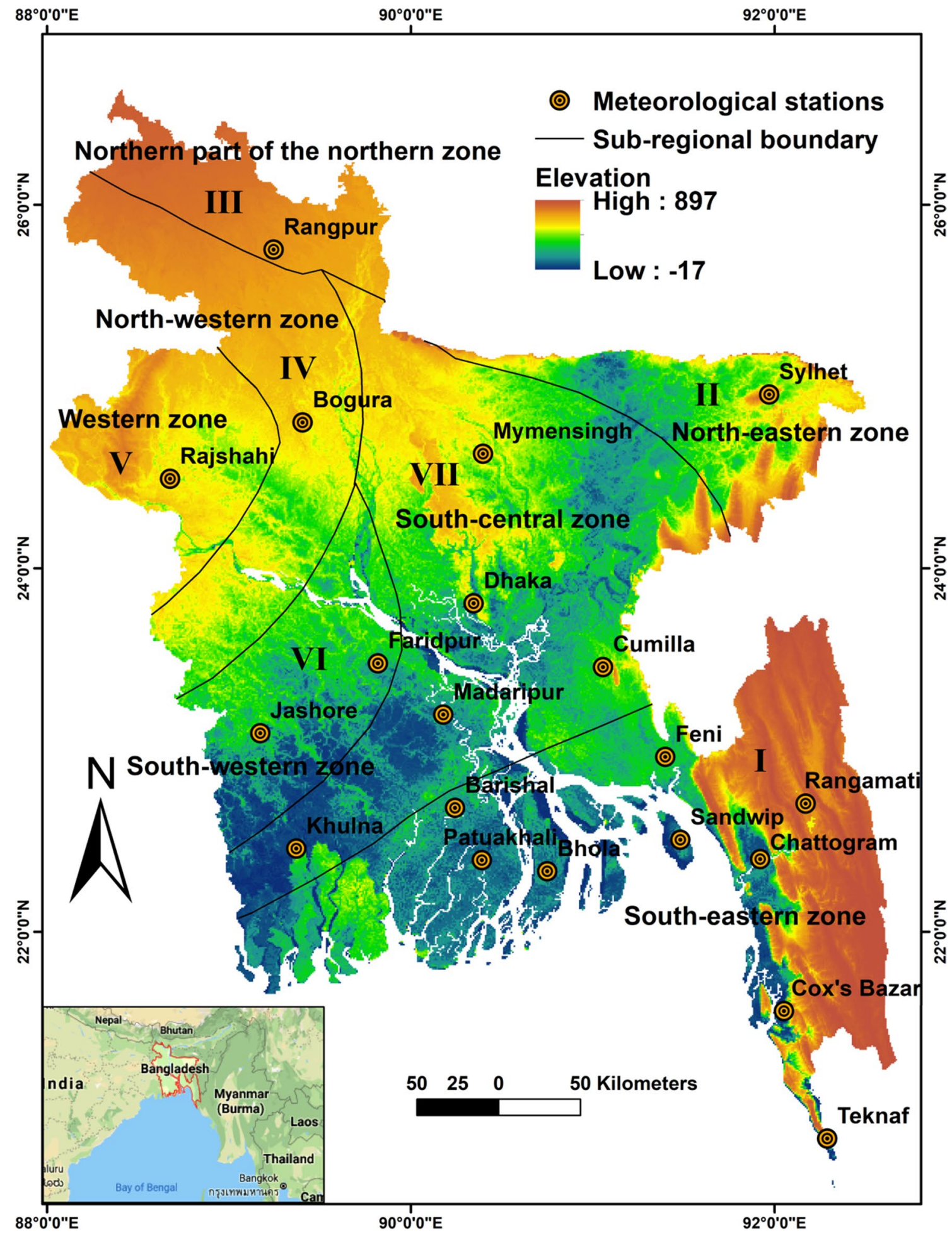

Figure 1. Map showing the geographical location of study area, prepared by ArcGis 10.5 (www.esri.com).

\section{Data and methods}

Study area description and data sources. Bangladesh, situated in Southeast Asia, geographically it encompasses between $20^{\circ} 30^{\prime} \mathrm{N}$ and $26^{\circ} 45^{\prime} \mathrm{N}$ latitudes and $88^{\circ} 0^{\prime} \mathrm{E}$ to $92^{\circ} 45^{\prime} \mathrm{E}$ longitudes (Fig. 1). Banglapedia ${ }^{48}$ divided Bangladesh into seven climatic sub-regions based on climatology and geography as shown in the Supplementary Material of Figure S2. The seven sub-regions are (1) south-eastern zone; (2) north-eastern zone; (3) northern part of the northern zone; (4) north-western zone; (5) western zone; (6) south-western zone and (7) south-central zone. Bangladesh experiences a sub-tropical humid monsoon climate with seasonal differences ${ }^{4}$. 
Western Bangladesh has usually become drier compared to other regions in Bangladesh ${ }^{49}$. Here, climatic variability is a regular scenario. Long-term daily average relative humidity, minimum temperature, maximum temperature, wind speed (at $2 \mathrm{~m}$ height), net radiation, evapotranspiration across the country are, respectively, $80 \%, 21.39^{\circ} \mathrm{C}, 29.94{ }^{\circ} \mathrm{C} 1.32 \mathrm{~ms}^{-1}, 10.44 \mathrm{MJm}^{-2} \mathrm{day}^{-1}$, and $3.72 \mathrm{~mm} \mathrm{day}^{-1}$.

Bangladesh Meteorological Department (BMD) runs only 43 meteorological stations across the country. The meteorological stations are unevenly distributed all over the country and most of the stations are located in the south-eastern regions. These meteorological stations are available for the climatic dataset, although some of the stations are newly established after the 1990s in Bangladesh and they do not have long-term data records (www.bmd.gov.bd). When more climatic variables are required, the dataset from a smaller number of stations was available. Due to these drawbacks, 20 stations were chosen for $\mathrm{ET}_{\mathrm{o}}$ estimation over the 38 years from 1980 to 2017. These selected 20 stations embody the seven climatic sub-regions of the country. Daily minimum $\left(\mathrm{T}_{\min }\right)$ and maximum temperature $\left(\mathrm{T}_{\max }\right)\left({ }^{\circ} \mathrm{C}\right)$, mean relative humidity $(\mathrm{Hr})(\%)$, wind speed $(\mathrm{Uz})$ (Knots) and sunshine hour $\left(\mathrm{h} \mathrm{day}^{-1}\right)$ datasets of 20 stations were sourced from the BMD. Net radiation $(\mathrm{Rn})$ and wind speed at $2 \mathrm{~m}$ height (U2) cannot directly be measured by weather stations. Daily Rn and U2 were estimated using the procedures recommended by Allen et al. ${ }^{1}$ with the available meteorological datasets. A brief geographical and meteorological description of the selected stations is found in the Supplementary Material of Table S2. However, missing data in almost all the 20 stations was found. After the initial screening test, missing data of the 20 stations were less than 5\% for the period of 1980-2017. Missing data for each station were filled by the existing records for the respective days from the adjacent neighbor stations. It is worthy to note that sunshine hour dataset in this study is continuous with no missing data. More details about the fill-up of missing meteorological datasets is given in the Supplementary Material (Table S3). The BMD follows the guideline of World Meteorological Organization (WMO) for weather dataset collection and record archiving. However, quality control of the dataset was primarily undertaken thoroughly by checking namely, positive values of parameters, for example, $\mathrm{T}_{\min }$ is lower than $\mathrm{T}_{\max }$, and humidity is less than $100 \%$. The homogeneity tests of the dataset were conducted to exhibit any anomaly in the datase ${ }^{50}$. All of the datasets were passed through the quality control by the staff of the BMD.

FAO56 Penman-Monteith model (FA056-PM model). The FAO56-PM equation is used for estimating daily $\mathrm{ET}_{\mathrm{o}}$ of this study. This model is well-known as the standard model for estimating $\mathrm{ET}_{\mathrm{o}}$ across the whole world, which was proposed by Allen et al. ${ }^{1}$ The original form of FAO56-PM model is expressed by the following Eq. (1):

$$
\mathrm{ET}_{\mathrm{o}}=\frac{0.408 \Delta\left(\mathrm{R}_{\mathrm{n}}-\mathrm{G}\right)+\gamma \frac{900}{\mathrm{~T}+273} \mathrm{U}_{2}\left(\mathrm{e}_{\mathrm{s}}-\mathrm{e}_{\mathrm{a}}\right)}{\Delta+\gamma\left(1+0.34 \mathrm{U}_{2}\right)}
$$

where, $\mathrm{ET}_{\mathrm{o}}$ is the reference evapotranspiration $\left(\mathrm{mm} \mathrm{day}^{-1}\right), \mathrm{R}_{\mathrm{n}}$ isthe net radiation atcrop surface $\left(\mathrm{MJm}^{-2} \mathrm{day}^{-1}\right)$, Gis the soil heat flux density $\left(\mathrm{MJ} \mathrm{m}^{-2}\right.$ day $\left.^{-1}\right), \mathrm{T}$ is the average daily air temperature at $2 \mathrm{~m}$ height $\left({ }^{\circ} \mathrm{C}\right), \mathrm{U}_{2}$ is the wind speed at $2 \mathrm{~m}$ height $\left(\mathrm{ms}^{-1}\right), \mathrm{e}_{\mathrm{s}}$ is the saturation vapour pressure $(\mathrm{kPa}), \mathrm{e}_{\mathrm{a}}$ is the actual vapour pressure $(\mathrm{kPa})$, $e_{s}-e_{a}$ is the saturation vapour pressure deficit $(\mathrm{kPa}), \Delta$ is the slope of vapour pressure curve $\left(\mathrm{kPa}^{\circ} \mathrm{C}^{-1}\right), \gamma$ is the psychrometric constant $\left(\mathrm{kPa}^{\circ} \mathrm{C}^{-1}\right)$. Allen et al. ${ }^{1}$ recommended $\mathrm{G}=0$. The detailed procedures of $\mathrm{ET}_{\mathrm{o}}$ estimation is found in FAO 56 paper $^{1}$.

$R_{n}$ is calculated by the Eqs. $(2-11)$ :

$$
\begin{gathered}
\mathrm{R}_{\mathrm{n}}=\mathrm{R}_{\mathrm{ns}}-\mathrm{R}_{\mathrm{nl}} \\
\mathrm{R}_{\mathrm{ns}}=(1-\alpha) \mathrm{R}_{\mathrm{s}} \\
\mathrm{R}_{\mathrm{s}}=\left[\mathrm{a}_{\mathrm{s}}+\mathrm{b}_{\mathrm{s}} \frac{\mathrm{n}}{\mathrm{N}}\right] \mathrm{R}_{\mathrm{a}} \\
\mathrm{Ra}=\frac{24(60)}{\pi} \mathrm{G}_{\mathrm{sc}} \mathrm{d}_{\mathrm{r}}\left[\omega_{\mathrm{s}} \sin (\varphi) \sin (\delta)+\cos (\varphi) \cos (\delta) \sin \left(\omega_{\mathrm{s}}\right)\right] \\
\mathrm{d}_{\mathrm{r}}=10.033 \cos \left(\frac{2 \pi}{365} \mathrm{~J}\right) \\
\delta=0.409 \sin \left(\frac{2 \pi}{365} \mathrm{~J}-1.39\right) \\
\mathrm{R}_{\mathrm{nl}}=\sigma\left[\frac{\mathrm{T}_{\text {max }} \mathrm{k}^{4}+\mathrm{T}_{\min } \mathrm{K}^{4}}{2}\right]\left(0.34-0.14 \sqrt{ } \mathrm{e}_{\mathrm{a}}\right)\left[1.35 \frac{\mathrm{R}_{\mathrm{s}}}{\mathrm{R}_{\mathrm{so}}}-0.35\right] \\
\operatorname{Radians}=\pi / 180(\mathrm{decimal} \operatorname{degrees}) \\
\arccos [-\tan (\varphi) \tan (\delta)]
\end{gathered}
$$




$$
\mathrm{R}_{\mathrm{so}}=\left(0.75+2 \times 10^{-5} \mathrm{Z}\right) \mathrm{R}_{\mathrm{a}}
$$

$\mathrm{U}_{2}$ is calculated from the following Eq. (12) recommended by Allen et al. ${ }^{1}$,

$$
\mathrm{U}_{2}=\mathrm{U}_{\mathrm{z}} \frac{4.87}{\operatorname{In}(67.8 \mathrm{z}-5.42)}
$$

where, $R_{n s}$ is the net solar or shortwave radiation $\left(M J m^{-2}\right.$ day $\left.{ }^{-1}\right), R_{n l}$ is the net outgoing longwave radiation $\left(\mathrm{MJ} \mathrm{m}^{-2}\right.$ day $\left.^{-1}\right), \mathrm{R}_{\mathrm{s}}$ is the global solar or shortwave radiation $\left(\mathrm{MJ} \mathrm{m}^{-2} \mathrm{day}^{-1}\right), \mathrm{N}$ and $\mathrm{n}$ are, respectively, the maximum and actual possible sunshine duration, $R_{a}$ is the extraterrestrial radiation $\left(\mathrm{MJ} \mathrm{m}^{-2} \mathrm{~d}^{-1}\right)$, Gsc is the solar constant $\left(0.0820 \mathrm{MJ} \mathrm{m}^{-2} \mathrm{~min}^{-1}\right), \mathrm{d}_{\mathrm{r}}$ is the inverse relative distance Earth-Sun, $\omega_{\mathrm{s}}$ is the sunset hour angle $(\mathrm{rad}), \varphi$ is latitude ( $\mathrm{rad}), \delta$ is solar declination ( $\mathrm{rad}$ ), $\mathrm{J}$ is the number of the day in the year between 1 (1 January) and 365 or 366 (31 December), $\sigma$ is the Stefan-Boltzmann constant $\left(4.903 \times 10^{-9} \mathrm{MJ} \mathrm{K}^{-4} \mathrm{~m}^{-2}\right.$ day $\left.^{-1}\right)$, $\alpha$ is albedo $(\alpha=0.23)$, $\mathrm{T}_{\max } \mathrm{k}$ and $\mathrm{T}_{\min } \mathrm{k}$ are, respectively, the maximum and minimum absolute temperatures during $24-\mathrm{h}$, and $\mathrm{R}_{\mathrm{so}}$ is the clear sky solar radiation $\left(\mathrm{MJ} \mathrm{m}^{-2}\right.$ day $\left.^{-1}\right)$. Allen et al. ${ }^{1}$ recommended 0.25 for $\mathrm{a}_{\mathrm{s}}$ and 0.50 for $\mathrm{b}_{\mathrm{s}}$. $\mathrm{U}_{\mathrm{z}}$ is measured wind speed at $Z_{\mathrm{m}}$ above ground surface $\left(\mathrm{ms}^{-2}\right)$ and $\mathrm{z}$ is respective station elevation above sea level $(\mathrm{m})$.

According to Allen et al. ${ }^{1}$, Saturation Vapour Pressure $\left(\mathrm{e}_{\mathrm{s}}\right)$, Actual Vapour Pressure $\left(\mathrm{e}_{\mathrm{a}}\right)$, Slope Vapour Pressure Curve $(\Delta)$ and Psychrometric Constant $(\gamma)$ are calculated by the following Eqs. (13-19), respectively:

$$
\begin{gathered}
e_{s}=\frac{e^{0}\left(T_{\text {max }}\right)+e^{0}\left(T_{\text {min }}\right)}{2} \\
e^{0}\left(T_{\text {max }}\right)=0.6108 \exp \left[\frac{17.27 T_{\text {max }}}{T_{\text {max }}+237.3}\right] \\
e^{0}\left(T_{\text {min }}\right)=0.6108 \exp \left[\frac{17.27 T_{\text {min }}}{T_{\min }+237.3}\right] \\
e_{a}=\frac{H r(\operatorname{mean})}{100}\left[\frac{e^{0}\left(T_{\max }\right)+e^{0}\left(T_{\min }\right)}{2}\right] \\
\Delta=\frac{4098\left[0.6108 \exp \left(\frac{17.27 T}{T+237.3}\right)\right]}{(T+237.3)^{2}} \\
\gamma=\frac{C p P}{\varepsilon \lambda}=0.665 \times 10^{-3} \mathrm{P} \\
\mathrm{P}=101.3\left(\frac{293-0.0065 Z}{293}\right)^{5.26}
\end{gathered}
$$

where, es is the mean saturation vapour pressure $(\mathrm{kPa}), e^{0}\left(T_{\max }\right) \operatorname{ande}^{0}\left(\mathrm{~T}_{\min }\right)$ are the saturation vapor pressure at maximum and minimum temperature, respectively. $e_{a}$ is the actual vapour pressure function $(\mathrm{kPa})$ and $\mathrm{Hr}$ is the mean relative humidity. $\mathrm{T}_{\mathrm{ave}}, \mathrm{T}_{\max }$ and $\mathrm{T}_{\min }$ are the mean, maximum and minimum air temperature, respectively, in ${ }^{\circ} \mathrm{C}$ and $\exp [\cdot]$ is 2.7183 (base of natural logarithm) raised to the power [..]. $\mathrm{P}$ is the atmospheric pressure $(\mathrm{kPa}), \lambda$ is the latent heat of vaporization $(2.45 \mathrm{MJ} \mathrm{kg}-1), \mathrm{C}_{\mathrm{p}}$ is the specific heat at constant pressure $\left(1.013 \times 10-3 \mathrm{MJ} \mathrm{kg}^{-1}{ }^{\circ} \mathrm{C}^{-1}\right), \varepsilon$ is the ratio molecular weight of water vapour/dry air $(0.622)$.

Empirical models. A primary survey of literature clearly showed that the $13 \mathrm{ET}_{\mathrm{o}}$ empirical model performed usually well in various sub-regions worldwide. Abtew ${ }^{51}$, Jensen and Haise ${ }^{52}$, Irmak ${ }^{53}$, Makkink ${ }^{54}$, Priestley-Taylor ${ }^{55}$, Hargreaves-Samani ${ }^{13}$, Berti $^{56}, \mathrm{WMO}^{30}$, Tabari $^{40}$, and Turc ${ }^{57}$ models were chosen to compare to the FAO56-PM model. The 13 empirical models were chosen based on the available input meteorological variables, universal acceptance and their applicability worldwide (Table S1). The Hargreaves-Samani (HS), Hargreaves M1 (HM1), Hargreaves M2 (HM2) and Berti models used in this study, as the HS, HM1 and HM2 models require only the temperature and extraterrestrial radiation datasets and Berti model requires only temperature data, making these models less complex. Therefore, the 13 empirical models used in the present study can be classified into the three classes: four temperature-based model (Hargreaves-Samani, Hargreaves M1, Hargreaves M2, and Berti), one mass transfer-based models (WMO), eight radiation-based models (Makkink, Priestly-Taylor, Jensen-Haise, Abtew, Irmak1, Irmak2, Tabari, and Turc). The performances and application of these models had never been validated in Bangladesh so far. The studied models, input parameters, computed equations with references are outlined in Table 1 .

Performance evaluation of $\mathbf{1 3}$ empirical models. Performance evaluation of 13 empirical models, based on the accuracy of each model for estimating $\mathrm{ET}_{\mathrm{o}}$, was undertaken by six statistical criteria. The six statistical criteria were the mean bias error $(\mathrm{MBE})^{58}$; mean absolute error (MAE), correlation of determination $\left(\mathrm{R}^{2}\right)$, 


\begin{tabular}{|c|c|c|c|c|}
\hline Sl. no. & Models & Models input & Equations & Proposed by \\
\hline \multicolumn{5}{|c|}{ Temperature-based } \\
\hline $\mathrm{ET}_{0,1}$ & Hargreaves-Samani & $\mathrm{R}_{\mathrm{a}}, \mathrm{T}_{\mathrm{ave}}, \mathrm{T}_{\max }, \mathrm{T}_{\min }$ & $\mathrm{ET}_{0,1}=\left[0.0023 \times \mathrm{Ra}\left(\mathrm{T}_{\text {ave }}+17.8\right)\left(\mathrm{T}_{\max }-\mathrm{T}_{\min }\right)^{0.5}\right] / \lambda$ & Hargreaves and Samani ${ }^{13}$ \\
\hline $\mathrm{ET}_{0,2}$ & Hargreaves M1 & $\mathrm{R}_{\mathrm{a}}, \mathrm{T}_{\mathrm{ave}}, \mathrm{T}_{\max }, \mathrm{T}_{\min }$ & $\mathrm{ET}_{0,2}=\left[0.408 \times 0.0030 \times\left(\mathrm{T}_{\text {ave }}+20\right)\left(\mathrm{T}_{\max }-\mathrm{T}_{\min }\right)^{0.4} \times \mathrm{Ra}\right.$ & Hargreaves and Samani ${ }^{13}$ \\
\hline $\mathrm{ET}_{0,3}$ & Hargreaves M2 & $\mathrm{R}_{\mathrm{a}}, \mathrm{T}_{\mathrm{ave}}, \mathrm{T}_{\max }, \mathrm{T}_{\min }$ & $\mathrm{ET}_{0,3}=0.408 \times 0.0023 \times($ Tave +17.8$) \times\left(T_{\max }-T_{\min }\right)^{0.424} \times R_{a}$ & Hargreaves and Samani ${ }^{13}$ \\
\hline $\mathrm{ET}_{0,4}$ & Berti & $\mathrm{R}_{\mathrm{a}}, \mathrm{T}_{\mathrm{ave}}, \mathrm{T}_{\max }, \mathrm{T}_{\min }$ & $\mathrm{ET}_{0,3}=\left[0.00193 R a\left(T_{\text {ave }}+17.8\right)\left(T_{\max }-T_{\min }\right)^{0.517}\right] / \lambda$ & Bertiet al. $^{56}$ \\
\hline \multicolumn{5}{|c|}{ Mass transfer-based } \\
\hline $\mathrm{ET}_{0,5}$ & WMO & $\mathrm{U}_{2}, \mathrm{e}_{\mathrm{s}}-\mathrm{e}_{\mathrm{a}}$ & $\mathrm{ET}_{0,4}=\left(0.1298+0.0934 \mathrm{U}_{2}\right)\left(\mathrm{e}_{\mathrm{s}}-\mathrm{e}_{\mathrm{a}}\right)$ & $\mathrm{WMO}^{30}$ \\
\hline \multicolumn{5}{|c|}{ Radiation-based } \\
\hline $\mathrm{ET}_{0,6}$ & Abtew & $\mathrm{R}_{\mathrm{s}}, \mathrm{T}_{\max }$ & $\mathrm{ET}_{0,5}=\frac{1}{56} \frac{R_{s} T_{\max }}{\lambda}$ & Abtew $^{51}$ \\
\hline $\mathrm{ET}_{0,7}$ & Irmak1 & $\mathrm{R}_{\mathrm{s}}$, Tave & $\mathrm{ET}_{0,6}=0.149 R_{s}+0.079$ Tave -0.611 & Irmak et al. ${ }^{53}$ \\
\hline $\mathrm{ET}_{0,8}$ & Irmak2 & $\mathrm{R}_{\mathrm{n}}, \mathrm{T}_{\text {ave }}$ & $\mathrm{ET}_{0,7}=0.489+0.289 \mathrm{R}_{\mathrm{n}}+0.023 \mathrm{~T}_{\text {ave }}$ & Irmak et al. ${ }^{53}$ \\
\hline $\mathrm{ET}_{0,9}$ & Makkink & $\mathrm{R}_{\mathrm{s}}, \mathrm{T}_{\mathrm{ave}}$ & $\mathrm{ET} 0,8=0.61 \frac{1}{\lambda}\left[\frac{\Delta}{\Delta+\gamma}\right] \mathrm{R}_{\mathrm{s}}-0.12$ & Makkink $^{54}$ \\
\hline $\mathrm{ET}_{0,10}$ & Priestley-Taylor & $\mathrm{R}_{\mathrm{n}}, \mathrm{T}_{\text {ave }}$ & $\mathrm{ET}_{0,9}=1.26\left[\frac{\Delta}{\Delta+\gamma}\right]\left(\mathrm{R}_{\mathrm{n}}-\mathrm{G}\right) / \lambda$ & Priestley and Taylor ${ }^{55}$ \\
\hline $\mathrm{ET}_{0,11}$ & Jensen-Haise & $\mathrm{R}_{\mathrm{s}}, \mathrm{T}_{\text {ave }}$ & $\mathrm{ET}_{0,10}=(0.025$ Tave +0.08$) \frac{\mathrm{R}_{\mathrm{s}}}{\lambda}$ & Jensen and Haise ${ }^{52}$ \\
\hline $\mathrm{ET}_{0,12}$ & Tabari & $\mathrm{R}_{\mathrm{s}}, \mathrm{T}_{\min }, \mathrm{T}_{\max }$ & $\mathrm{ET}_{0,11}=0.156 \mathrm{R}_{\mathrm{s}}-0.0112 \mathrm{~T}_{\max }+0.0733 \mathrm{~T}_{\min }-0.478$ & Tabari et al..$^{40}$ \\
\hline $\mathrm{ET}_{\mathrm{o}, 13}$ & Turc & $\mathrm{R}_{\mathrm{s}}, \mathrm{T}_{\text {ave }}$ & $\mathrm{ET}_{0,13}=0.013 \frac{T_{\text {ave }}}{T_{\text {vve }}+15}(R s+50)$ & $\operatorname{Turc}^{57}$ \\
\hline
\end{tabular}

Table 1. The original form of the 13 empirical models associated with the input parameters. $\mathrm{T}_{\mathrm{ave}}, \mathrm{T}_{\max }$, and $\mathrm{T}_{\min }$ are the mean (average), maximum, and minimum temperature $\left({ }^{\circ} \mathrm{C}\right)$, respectively and $\lambda$ is the latent heat of vaporization $\left(2.45 \mathrm{MJ} \mathrm{kg}^{-1}\right), \mathrm{a}_{\mathrm{w}}=0.3+0.58 \exp \left[-\left(\frac{\mathrm{J}-170}{45}\right)^{2}\right]$ and $\mathrm{b}_{\mathrm{w}}=0.32+0.54 \exp \left[-\left(\frac{\mathrm{J}-228}{67}\right)^{2}\right]($ after Peng et al. $\left.{ }^{11}\right)$.

root mean square error (RMSE) $)^{43}$; relative error (RE), Nash-Sutcliffe efficacy coefficient (NSE) ${ }^{59}$ expressed by the following Eqs. (20-25):

$$
\begin{gathered}
M A E=\frac{1}{n} \sum_{i=1}^{n}\left|E T_{o, s}-E T_{o, i}\right| \\
M B E=\frac{1}{n} \sum_{i=1}^{n} E T_{o, i}-E T_{o, s} \\
N S E=1-\frac{\sum_{i=1}^{n}\left(E T_{o, s}-E T_{o, i}\right)^{2}}{\sum_{i=1}^{n}\left(E T_{o, s}-E T_{o, s}\right)^{2}} \\
R^{2}=\frac{\sum_{i=1}^{n}\left(E T_{o, s}-E T_{o, i}\right)^{2}}{\sum_{i=1}^{n}\left(E T_{o, s}-E T_{o, i}\right)^{2}} \\
R E=\frac{E T_{o, i}-E T_{o, s}}{E T_{o, s}} \\
R M S E=\sqrt{\frac{1}{n} \sum_{i=1}^{n}\left(E T_{o, s}-E T_{o, i}\right)^{2}}
\end{gathered}
$$

where, $\mathrm{ET}_{\mathrm{o}, \mathrm{s}}, \mathrm{ET}_{\mathrm{o}, \mathrm{i}}$ and $\mathrm{n}$ are the observed $\mathrm{ET}_{\mathrm{o}}$ (estimated by FAO56-PM), estimated $\mathrm{ET}_{\mathrm{o}}$ (estimated by empirical models) and total observations, respectively.

Modified Mann-Kendall test. Modified Mann-Kendall (MMK) test is a non-parametric test which was applied for detecting the increasing and decreasing trend of $\mathrm{ET}_{\mathrm{o}, \mathrm{s}}$ in Bangladesh during 1980-2017 ${ }^{60}$. To carry out this MKK test, it is imperative to confirm the serial autocorrelation of the time series dataset. Hence, the serial autocorrelation should be excluded before employing the MMK test. To exclude the serial autocorrelation, the trend free pre-whitening approach proposed by Yue and Wang ${ }^{61}$ has been utilized. The original form of $\mathrm{MK}$ test $^{62,63}$ statistics $(\mathrm{S})$ is as followed: 


$$
\begin{gathered}
S=\sum_{i=1}^{n-1} \sum_{j=i+1}^{n} \operatorname{sgn}\left(X_{j}-X_{i}\right) \\
\operatorname{sgn}(\theta)= \begin{cases}1 & \text { if } \theta>0 \\
0 & \text { if } \theta=0 \\
-1 & \text { if } \theta=0\end{cases}
\end{gathered}
$$

Direction of increasing or decreasing trend is indicated by S. The variance ${ }^{64}$ of $S$ is followed by the Eq. (29):

$$
V(S)=\frac{n(n-1)(2 n+5)-\sum_{i=1}^{n} t_{i} i(i-1)\left(2 t_{i}+5\right)}{18}
$$

$\mathrm{V}^{\star}(\mathrm{S})$, is the modified variance ${ }^{61}$ given by following Eq. (30):

$$
V^{*}(S)=V(S) \cdot \frac{n}{n^{*}}
$$

$\mathrm{n} / \mathrm{n}^{\star}$ is termed as correction factor and denoted ${ }^{65}$ by following Eq. (31):

$$
\frac{n}{n^{*}}=1+2 \cdot \sum_{k=1}^{n-1}\left(1-\frac{k}{n}\right) \cdot \rho_{k}
$$

Test statistic $\mathrm{Z}$ is calculated by following Eq. (32):

$$
Z= \begin{cases}\frac{S-1}{\sqrt{V^{*}(S)}} & S>0 \\ 0 & S=0 \\ \frac{S+1}{\sqrt{V^{*}(S)}} & S<0\end{cases}
$$

Positive $\mathrm{Z}$ statistic indicates increasing trend of $\mathrm{ET}_{\mathrm{o}, \mathrm{s}}$ and negative $\mathrm{Z}$ statistic indicates decreasing trend of $\mathrm{ET}_{\mathrm{o}, \mathrm{s}}$ in Bangladesh.

Sen's slope of estimator. Sen's slope of estimator ${ }^{66}$ was applied for calculating the change of $\mathrm{ET}_{\mathrm{o}, \mathrm{s}}$ in Bangladesh per decade and the statistics is as followed:

$$
\mathrm{Q}=x j-x k j
$$

$\mathrm{Q}$ is denoted as the slope between $x j$ and $x k$.

The spatial distributions of the monthly $E T_{\mathrm{o}}$ and its trends are mapped.

Spatial distributions of the monthly meteorological variables; $\mathrm{ET}_{\mathrm{o}, \mathrm{s}}, \mathrm{ET}_{\mathrm{o}, \mathrm{i}}$, trends and the other examined variables are mapped by the inverse distance weighted interpolation model in ArcGIS 10.5 software.

Random forest (RF) model. The RF is a heuristic decision tree-based supervised machine learning model $^{67}$ that is appropriate for addressing the existence of the over-fitting problem to the decision trees, and other machine learning algorithm ${ }^{68}$. The $\mathrm{RF}$ is most robust, can handle numerous heterogeneous covariates, and has been effectively employed into the hydrological field ${ }^{69}$, genetic engineering field ${ }^{70}$ and hydro-meteorological field $^{71}$. The RF model has been benefited from the two more powerful algorithms e.g., bagging and random binary trees, which are called the powerhouse of this model. For developing the RF model, the number of trees and features in each split is essential. RF is a classifier which comprises of an assortment of classifier trees $f_{m}(x)$ for $m=1, \ldots, M$ which relies on the parameters and every single tree casts a unit vote for input $x^{71}$. Each tree generates an individual class which then combined and the majority vote predicts the final results. Present study optimized its accuracy with 100 trees, 1 execution slot, 5 seeds and with maximum depth 1 . As a tree-based ensemble learning model, this model has extensively used to evaluate the importance degree of any climatic dataset in various regions ${ }^{25,72}$. To the best of author's knowledge, the RF model has not yet been employed to explore the importance degree of 13 empirical models against the FAO56-PM model in Bangladesh. The RF model is used to know which model is most reliable and dominant for estimating $\mathrm{ET}_{\mathrm{o}}$. More detailed about the RF model can be found elsewhere ${ }^{46,71}$.

\section{Results}

Spatial distribution of meteorological variables. Figure 2 represents the distribution of multi-year mean meteorological variables of $\mathrm{T}_{\text {ave }}, \mathrm{T}_{\min }, \mathrm{T}_{\max }, \mathrm{Rn}, \mathrm{U} 2$, and Hr from 1980 to 2017. Distribution of $\mathrm{T}_{\text {ave }}$ (Fig. 2a), $\mathrm{T}_{\min }$ (Fig. 2b) and $\mathrm{T}_{\max }$ (Fig. 2c) showed almost similar results. Sub-region VI showed the higher values of historical temperature, while sub-regions II and III entirely showed the lowest temperature. Sub-region V showed the lowest temperature for the distribution of $\mathrm{T}_{\text {ave }}$ and $\mathrm{T}_{\min }$ and moderate temperature for $\mathrm{T}_{\max }$. Sub-regions $\mathrm{I}$, IV and VII showed the moderate values. The higher rate of net radiation was observed in the sub-region I and lower rate of net radiation was found in the sub-regions II and III (Fig. 2d). Average values of Rn were seen in the sub-regions IV, V, VI, and VII. The highest wind speed was found in the sub-region of VI and the lowest in the sub-regions II, III and V (Fig. 2e). Sub-region I experienced a comparatively higher rate of $\mathrm{Hr}$ as it located 

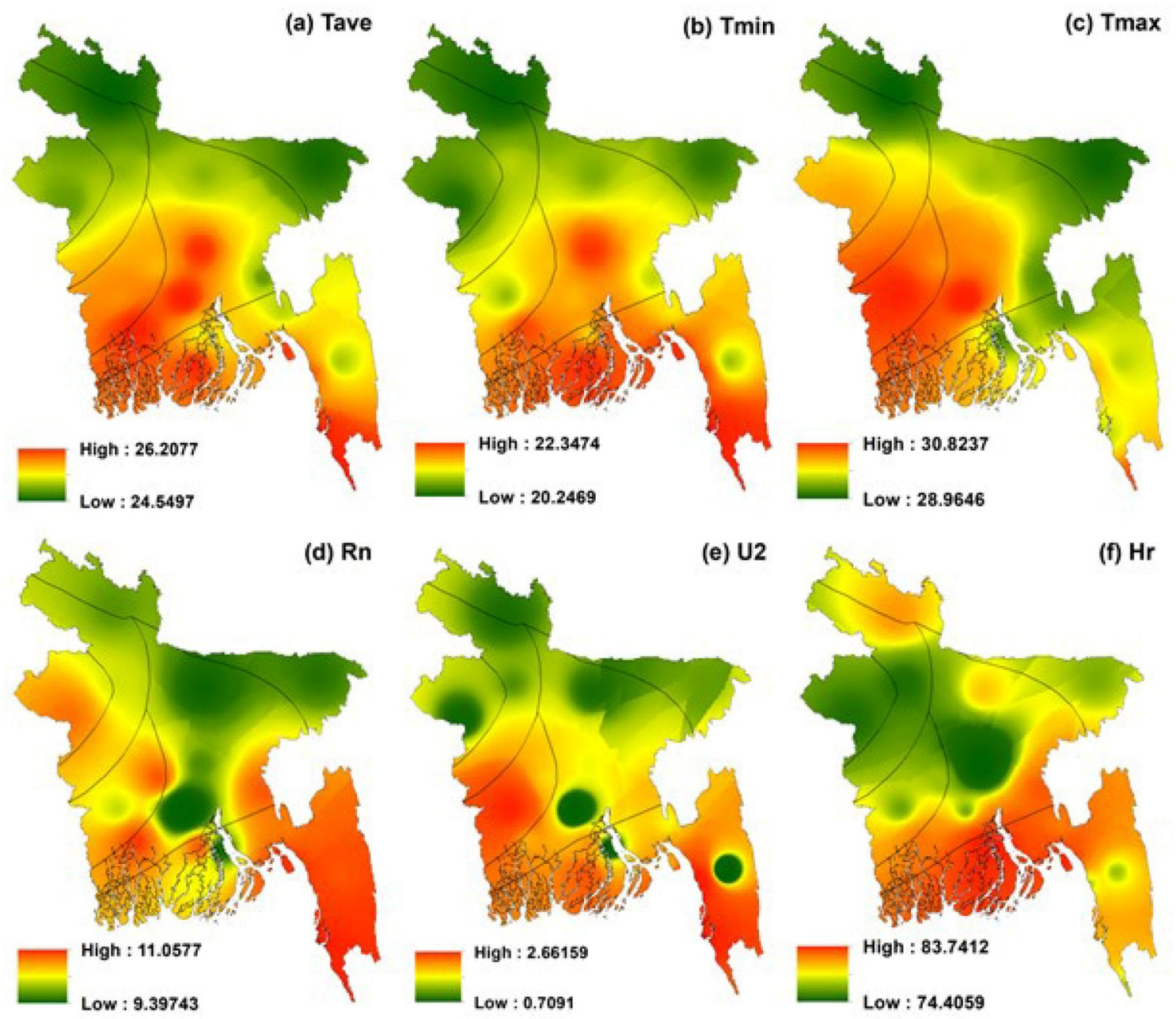

Figure 2. Spatial distribution of multi-year mean meteorological variables in Bangladesh, prepared by ArcGis 10.5 (www.esri.com).

near the Bay of Bengal from where this region took available moisture and sub-region $\mathrm{V}$ experienced the lower rate of $\mathrm{Hr}$ (Fig. 2f).

Spatial and temporal patterns of $\mathbf{E T}_{\mathrm{o}, \mathrm{s}}$ and $\mathrm{ET}_{\mathrm{o}, \mathrm{i}}$. Figure 3 represents the long-term multi-year mean monthly trends of $\mathrm{ET}_{\mathrm{o}, \mathrm{S}}$ (FAO56-PM). Most parts of sub-regions I and VII showed the higher values of MMK-Z statistic and the sub-regions III, IV and V showed the lowest values of MMK-Z statistic (Fig. 3a). Moderate values are shown in the sub-regions II and VI. In general, the rates between increasing and decreasing of $\mathrm{ET}_{\mathrm{o}, \mathrm{s}}$ was from 72.18 to $-72.17 \mathrm{~mm}$ per decade (Fig. $3 \mathrm{~b}$ ). Figure $3 \mathrm{c}$ shows the nature of the trend whether it was significant or insignificant. The significant increasing trend of $\mathrm{ET}_{\mathrm{o}, \mathrm{s}}$ was detected in Bhola, Cumilla, Feni $(\alpha=0.01)$; Rangamati, and Patuakhali $(\alpha=0.05)$ in the sub-regions I and VII.

All the weather stations of sub-regions II $(\alpha=0.1)$; III, IV $(\alpha=0.01)$ and V $(\alpha=0.05)$ showed a significant decreasing trend of $\mathrm{ET}_{\mathrm{o}, \mathrm{s}}$. Faridpur, Madaripur, Dhaka and Barishal of sub-regions I and VII showed an insignificant decreasing trend of $\mathrm{ET}_{\mathrm{o}, \mathrm{s}}$. Cox's Bazar $(\alpha=0.05)$; Teknaf, Sandwip and Chattogram $(\alpha=0.01)$ of sub-region I; Jashore $(\alpha=0.05)$ of sub-region VI and Mymensingh $(\alpha=0.01)$ and Khulna $(\alpha=0.1)$ of sub-region VII showed a significant decreasing trend of $\mathrm{ET}_{\mathrm{o}, \mathrm{s}}$.

Spatial distribution of multi-year mean monthly $\mathrm{ET}_{\mathrm{o}, \mathrm{s}}$ and $\mathrm{ET}_{\mathrm{o}, \mathrm{i}}$ from 1980 to 2017 is presented in Fig. 4. The higher value $(4.12 \mathrm{~mm})$ of $\mathrm{ET}_{\mathrm{o}, \mathrm{s}}$ seen in the sub-regions $\mathrm{V}$, $\mathrm{VI}$ and some parts of region $\mathrm{I}$. The lower value $(3.46 \mathrm{~mm})$ of $\mathrm{ET}_{\mathrm{o}, \mathrm{s}}$ seen in the sub-regions II, III and some part of the sub-regions I, IV and VII. The distribution of $\mathrm{ET}_{\mathrm{o}, \mathrm{i}}$ showed the homogeneous distribution of $\mathrm{ET}_{\mathrm{o}, \mathrm{s}}$. The high-low values of spatial distribution of $\mathrm{ET}_{\mathrm{o}, 1}$ (temperature-based); $\mathrm{ET}_{0,6} ; \mathrm{ET}_{0,7} ; \mathrm{ET}_{0,10}$ (radiation-based) models were analogous with that of $\mathrm{ET}_{0,5}$. $\mathrm{ET}_{0,5}$ (mass transfer-based) and $\mathrm{ET}_{\mathrm{o}, 13}$ (radiation-based) models showed the most heterogeneity with $\mathrm{ET}_{\mathrm{o}, \mathrm{s}}$. Sub-regions $\mathrm{V}$ and VI showed the highest value of ETo (computed by most of the empirical models and FAO56-PM) and all the models found that the sub-regions II and III experienced a lower rate of ETo. All the models revealed that moderate ETo was experienced by the sub-regions I, IV and VII. Approximately, similar zonation (based on the highest and lowest values) was observed between $\mathrm{ET}_{\mathrm{o}, \mathrm{s}}$ and $\mathrm{ET}_{\mathrm{o}, 6}$. 


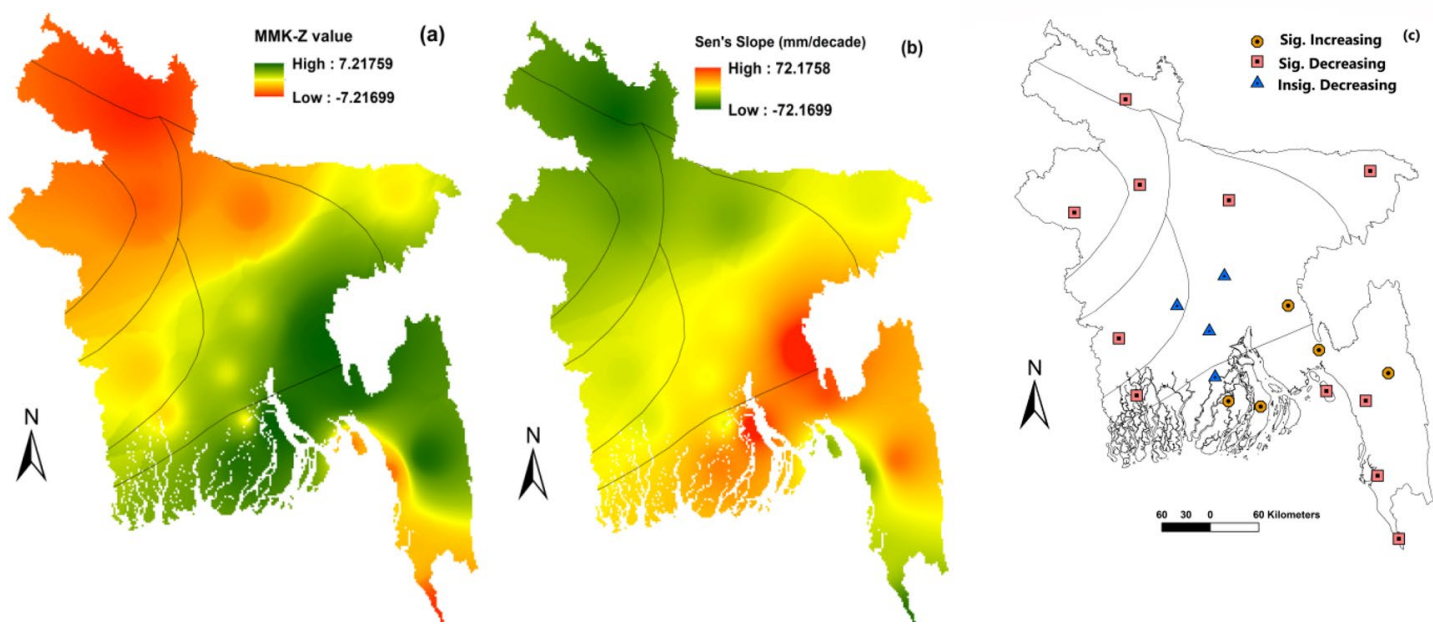

Figure 3. Representation of the multi-year mean monthly $\mathrm{ET}_{\mathrm{o}, \mathrm{s}}$ trends of (a) $\mathrm{MMK}-\mathrm{Z}$ values (mm); (b) Sen's slope estimation and (c) station wise increasing or decreasing trends of Bangladesh, prepared by ArcGis 10.5 (www.esri.com).

Temporal distribution of long-term monthly $\mathrm{ET}_{\mathrm{o}, \mathrm{s}}$, and $\mathrm{ET}_{\mathrm{o}, \mathrm{i}}$ in different sub-regions, as well as whole Bangladesh for the period of 1980-2017, is shown in Fig. 5. The highest rate of reference evapotranspiration (ET $\mathrm{o}_{\mathrm{o}, \mathrm{s}}$ and $\mathrm{ET}_{\mathrm{o}, \mathrm{i}}$ ) occurred in April in all the regions of Bangladesh. The lowest $\mathrm{ETo}$ (both $\mathrm{ET}_{\mathrm{o}, \mathrm{s}}$ and $\mathrm{ET}_{\mathrm{o}, \mathrm{i}}$ ) found in January and December. Except for sub-regions II and III, the range of the rate of $\mathrm{ET}_{\mathrm{o}, \mathrm{s}}$, and $\mathrm{ET}_{\mathrm{o}, \mathrm{i}}$ was the same in all the sub-regions. Among the 13 empirical models, $\mathrm{ET}_{0,5} ; \mathrm{ETo} 3$ (elevated the lowest values than $\mathrm{ET}_{\mathrm{o}, \mathrm{s}}$ ) and $\mathrm{ET}_{\mathrm{o}, 11}$

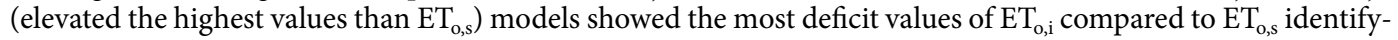
ing least suitable method for estimating ETo. Conversely, the values estimated by $\mathrm{ET}_{0,6}$ showed the closest values to $\mathrm{ET}_{\mathrm{o}, \mathrm{s}}$ demonstrating as the most preferable model for estimating $\mathrm{ETo}_{\mathrm{N}} \mathrm{ET}_{\mathrm{o}, 1}$ and $\mathrm{ET}_{\mathrm{o}, 7}$ also estimated values with the smallest difference with $\mathrm{ET}_{\mathrm{o}, \mathrm{s}}$ in all the regions, confirmed as the preferable method for estimating ETo. Moderate values estimated by $\mathrm{ET}_{\mathrm{o}, 2} ; \mathrm{ET}_{\mathrm{o}, 4} ; \mathrm{ET}_{\mathrm{o}, 8} ; \mathrm{ET}_{\mathrm{o}, 9} ; \mathrm{ET}_{\mathrm{o}, 10}$ and $\mathrm{ET}_{\mathrm{o}, 12}$ models compared to $\mathrm{ET}_{\mathrm{o}, \mathrm{s}}$.

Long term inter-annual variation of $\mathrm{ET}_{\mathrm{o}, \mathrm{s}}$, and $\mathrm{ET}_{\mathrm{o}, \mathrm{i}}$ from 1980 to 2017 are represented by Fig. 6. It also demonstrates similar results as shown in Fig. 5. The largest deviation from the $\mathrm{ET}_{\mathrm{o}, \mathrm{s}}$ values occurred by estimating $\mathrm{ET}_{0, \mathrm{i}}$ (values lower than 1) by both $\mathrm{ET}_{0,5}$ and $\mathrm{ET}_{\mathrm{o}, 13}$ models. The Fig. 6 shows that the rate of ETo in each sub-region along with whole Bangladesh, estimated by both $\mathrm{ET}_{\mathrm{o}, \mathrm{s}}$ and $\mathrm{ET}_{\mathrm{o}, \mathrm{i}}$ models, declined gradually. Unlike the multi-year monthly distribution, the range (from 0 to $5.5 \mathrm{~mm}$ ) of ETo values was nearly similar in every sub-regions and Bangladesh. Like the multi-year monthly distribution, $\mathrm{ET}_{0,6} ; \mathrm{ET}_{0,1} ; \mathrm{ET}_{0,7}$ and $\mathrm{ET}_{0,10}$ showed the very closest values to $\mathrm{ET}_{\mathrm{o}, \mathrm{s}}$ in each sub-region. Values larger than that of $\mathrm{ET}_{\mathrm{o}, \mathrm{s}}$ found by $\mathrm{ET}_{\mathrm{o}, 11}$. Based on the spatiotemporal distribution of $\mathrm{ET}_{\mathrm{o}, \mathrm{i}}$ estimated by 13 empirical models in each sub-region and whole Bangladesh, the empirical models can be ranked in ascending order based on the closest values to $\mathrm{ET}_{\mathrm{o}, \mathrm{s}}$ as $\mathrm{ET}_{\mathrm{o}, 6}>\mathrm{ET}_{\mathrm{o}, 1}>\mathrm{ET}_{\mathrm{o}, 7}>\mathrm{ET}_{\mathrm{o}, 10}>\mathrm{ET}_{\mathrm{o}, 3}>\mathrm{ET}_{\mathrm{o}, 2}>\mathrm{ET}_{\mathrm{o}, 12}>\mathrm{ET}_{\mathrm{o}, 4}>\mathrm{ET}_{\mathrm{o}, 8}>\mathrm{ET}_{\mathrm{o}, 9}>\mathrm{ET}_{0,11}>\mathrm{ET}_{0,13}>\mathrm{ET}_{0,5}$.

Performance appraisal of 13 empirical models for estimating ETo. Figure 7 shows the long term monthly RE of $\mathrm{ET}_{\mathrm{o}, \mathrm{i}}$ by spatial distribution for the period of 1980-2017. RE of the maximum $\mathrm{ET}_{\mathrm{o}, \mathrm{i}}$ covered mutually positive and negative values. The lowest $\mathrm{RE}$ was observed in $\mathrm{ET}_{\mathrm{o}, \mathrm{i}}$ calculated by $\mathrm{ET}_{\mathrm{o}, 6}$. Furthermore, $\mathrm{ET}_{\mathrm{o}, 1}$; $\mathrm{ET}_{\mathrm{o}, 7} ; \mathrm{ET}_{\mathrm{o}, 10}$ and $\mathrm{ET}_{\mathrm{o}, 12}$ models also produced lower $\mathrm{RE}$, respectively. The worst performance with the high $\mathrm{RE}$ belongs to the $\mathrm{ET}_{0,5}$ and $\mathrm{ET}_{0,13}$ models. The relative error in different sub-regions varied with the variation of different empirical models. The $\mathrm{ET}_{\mathrm{o}, 11}, \mathrm{ET}_{\mathrm{o}, 9}, \mathrm{ET}_{\mathrm{o}, 8}, \mathrm{ET}_{\mathrm{o}, 2}, \mathrm{ET}_{\mathrm{o}, 3}$ and $\mathrm{ET}_{\mathrm{o}, 4}$ models also recognized as the worst models, respectively, producing high $\mathrm{RE}$.

Table 2 shows the long term mean monthly and annual RMSE for 13 selected $\mathrm{ET}_{\mathrm{o}, \mathrm{i}}$ models for whole Bangladesh. The higher RMSE was produced by the $\mathrm{ET}_{0,5} ; \mathrm{ET}_{0,13}$ and $\mathrm{ET}_{0,11}$ models, respectively. The $\mathrm{ET}_{0,6}, \mathrm{ET}_{0,3}, \mathrm{ET}_{0,7}$ and $\mathrm{ET}_{\mathrm{o}, 1}$ models generated the least RMSE for calculating ETo. The descending order of the other models based on performance was $\mathrm{ET}_{0,2}>\mathrm{ET}_{0,9}>\mathrm{ET}_{0,4}>\mathrm{ET}_{0,10}>\mathrm{ET}_{0,8}>\mathrm{ET}_{0,12}$.

Table 3 represents the long term mean monthly and annual MAE values of 13 empirical models used for estimating $\mathrm{ET}_{\mathrm{o}, \mathrm{i}}$. Lower values of MAE indicates higher accuracy. Respectively, $\mathrm{ET}_{\mathrm{o}, 6}$ and $\mathrm{ET}_{\mathrm{o}, 1}$ models produced the smallest MAE values for both the monthly and annual $\mathrm{ET}_{\mathrm{o}, \mathrm{i}}$ values in Bangladesh. Higher MAE values produced by the models (respectively) of $\mathrm{ET}_{0,5}, \mathrm{ET}_{0,13}, \mathrm{ET}_{0,11}, \mathrm{ET}_{0,9}$ and $\mathrm{ET}_{\mathrm{o}, 8}$ in calculating both the monthly and annual $\mathrm{ET}_{\mathrm{o}, \mathrm{i}}$.

Table 4 shows the NSE coefficient of empirical models used for calculating $\mathrm{ET}_{\mathrm{o}, \mathrm{i}}$ at the annual and monthly time scale in Bangladesh. Approximately, all the models gave negative NSE value indicating the least correlated method with $\mathrm{ET}_{\mathrm{o}, \mathrm{s}}$. In both monthly and annual timescales, $\mathrm{ET}_{\mathrm{o}, 6}$ outperformed as it gave positive NSE value, except for the month of October and November. The performance accuracy of $\mathrm{ET}_{\mathrm{o}, 1}$ was comparatively higher than that of other models except for $\mathrm{ET}_{0,6}, \mathrm{ET}_{0,13}, \mathrm{ET}_{0,5}$ and $\mathrm{ET}_{0,11}$ models. In annual timescale, the order of the performance of the models was $\mathrm{ET}_{0,6}>\mathrm{ET}_{0,7}>\mathrm{ET}_{0,1}>\mathrm{ET}_{0,10}>\mathrm{ET}_{0,12}>\mathrm{ET}_{0,4}>\mathrm{ET}_{0,2}>\mathrm{ET}_{0,8}>\mathrm{ET}_{0,9}>\mathrm{ET}_{0,3}>\mathrm{ET}_{0,11}>\mathrm{ET}_{0,5}>\mathrm{ET}_{0,13}$. 

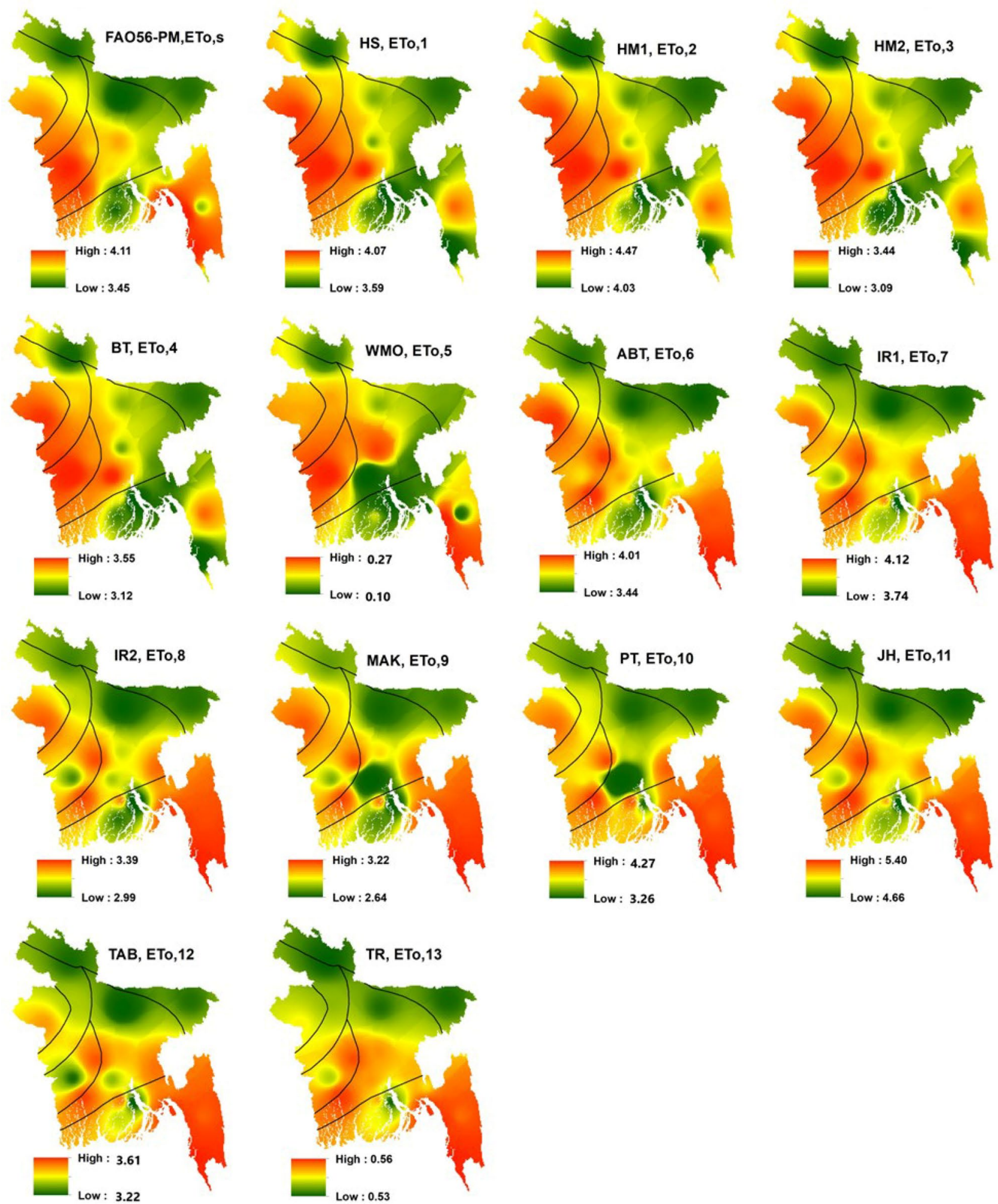

Figure 4. Spatial distribution of multi-year mean monthly $\mathrm{ET}_{\mathrm{o}, \mathrm{s}}$ and $\mathrm{ET}_{\mathrm{o}, \mathrm{i}}$ in Bangladesh, prepared by ArcGis 10.5 (www.esri.com). 

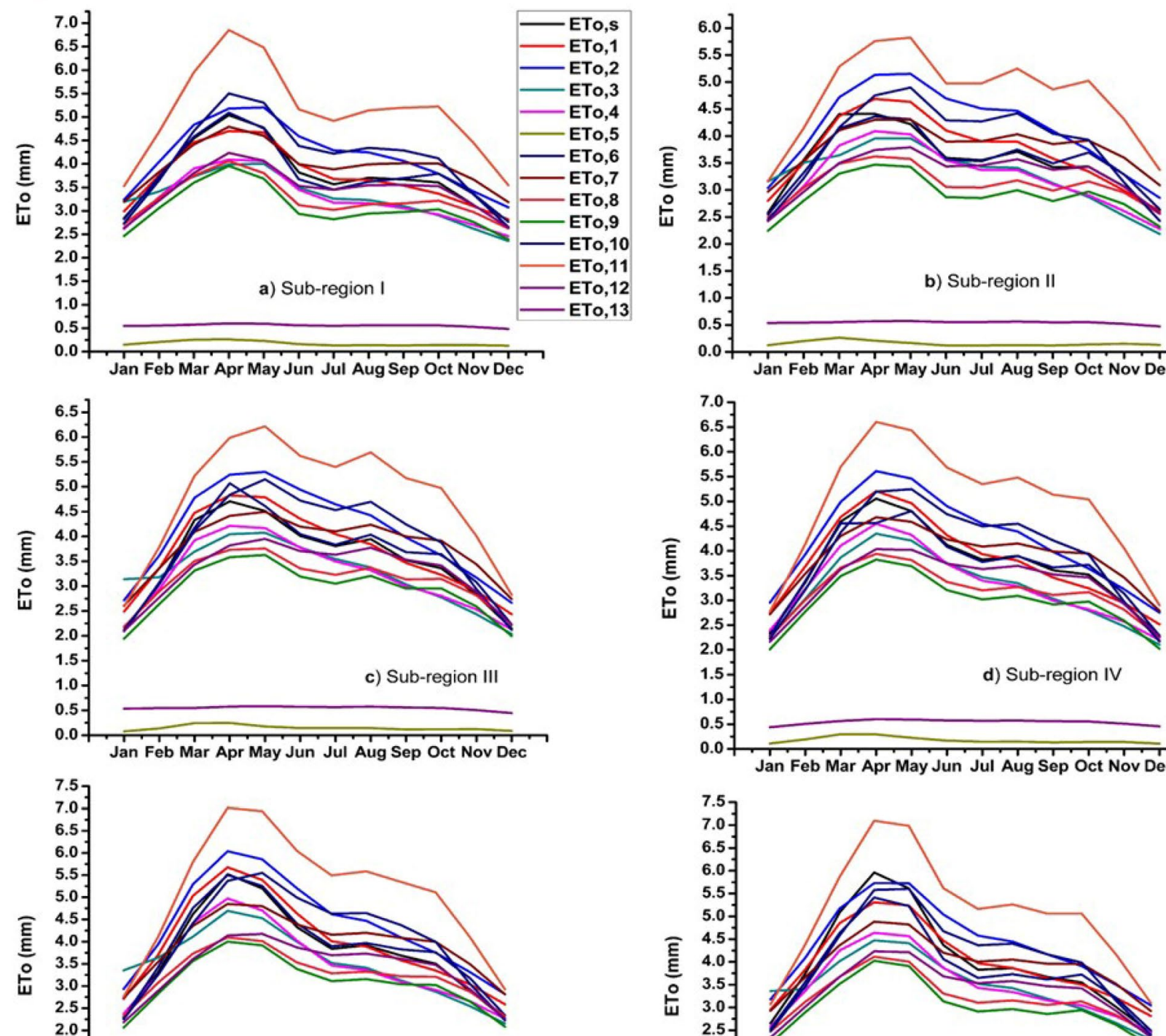

e) Sub-region $V$

Jan Feb Mar Apr May Jun Jul Aug Sep Oct Nov Dec

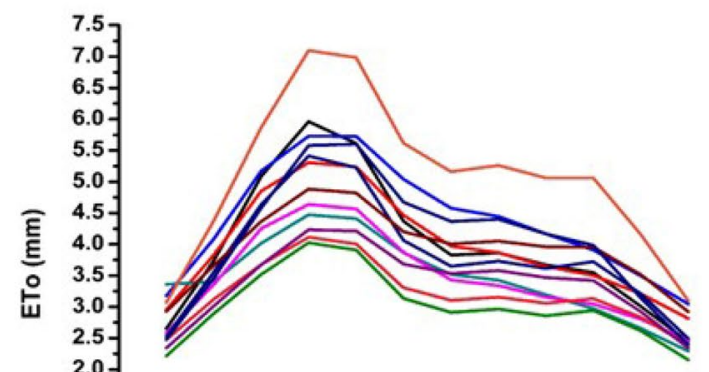

c) Sub-region III

$1.5-$

$1.0-1$

0.07 .

b) Sub-region II

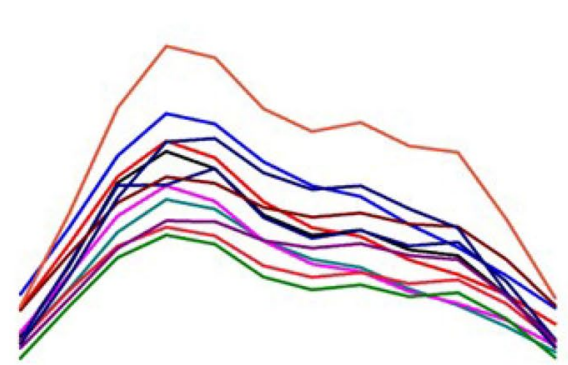

d) Sub-region IV

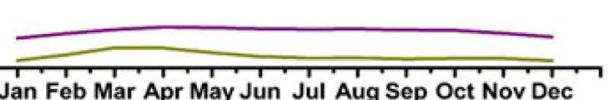

1.5

$1.0-$

$0.5-1$

$0.0+1, T$

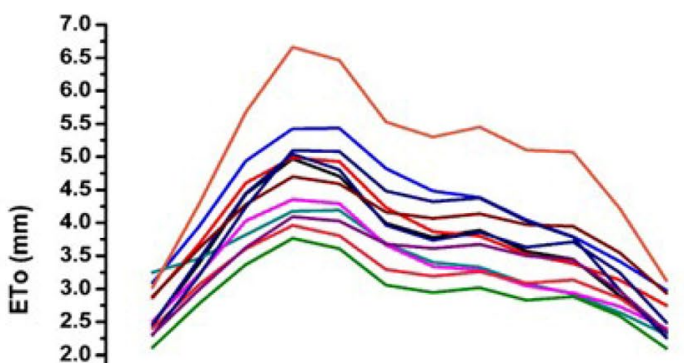

g) Sub-region VII

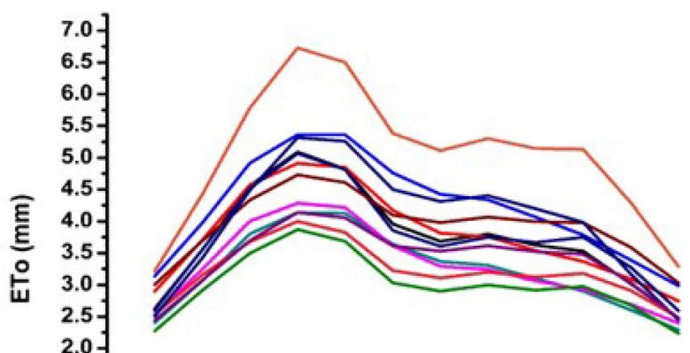

h) Whole Bangladesh

$$
\begin{aligned}
& 1.5 \\
& 1.0 \\
& 0.5 \\
& 0.0
\end{aligned}
$$

Jan Feb Mar Apr May Jun Jul Aug Sep Oct Nov Dec

Jan Feb Mar Apr May Jun Jul Aug Sep Oct Nov Dec

Figure 5. Temporal distribution of multi-year mean monthly $\mathrm{ET}_{\mathrm{o}, \mathrm{s}}$ and $\mathrm{ET}_{\mathrm{o}, \mathrm{i}}$ in different sub-regions and whole Bangladesh. 

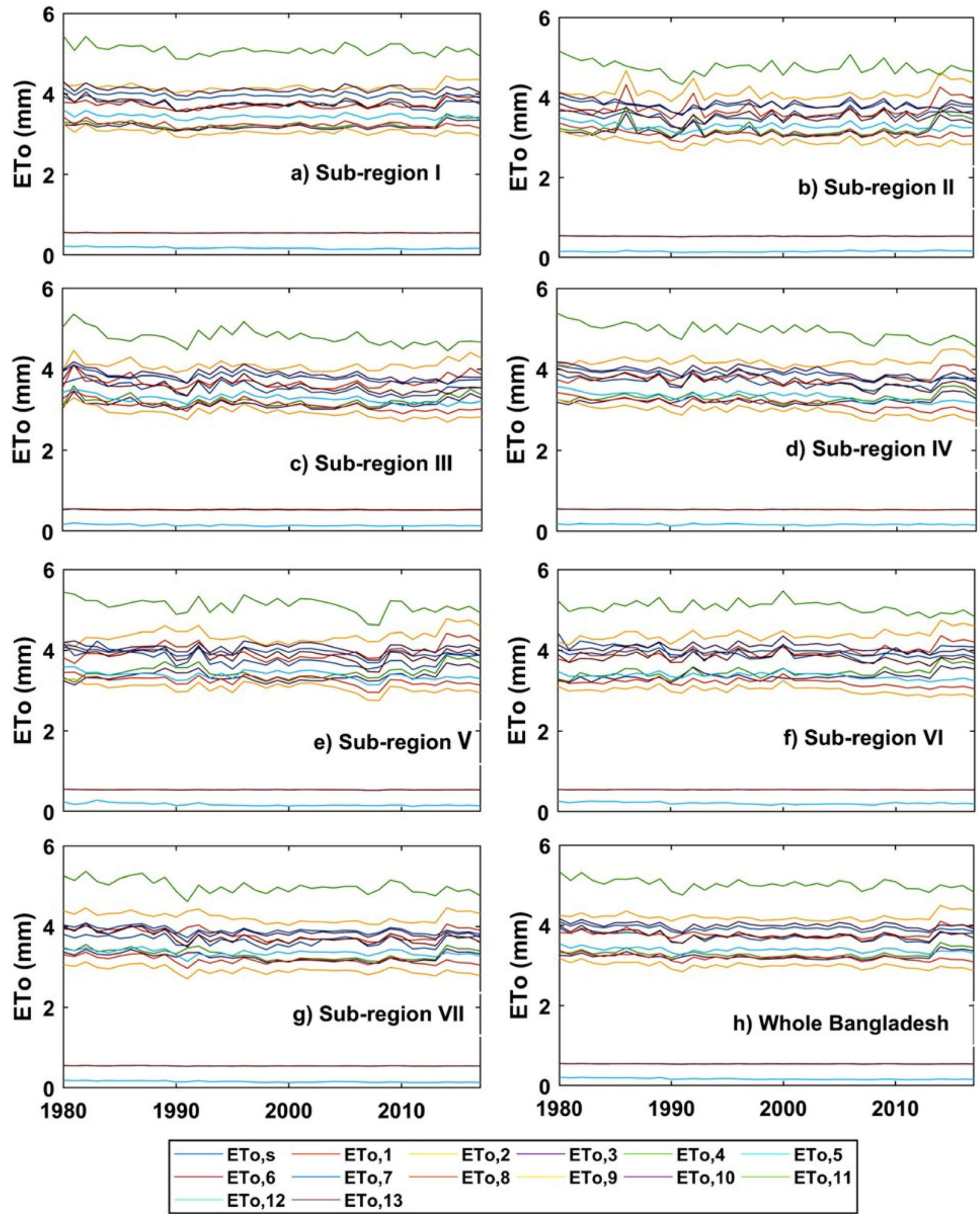

Figure 6. The inter-annual variations of $\mathrm{ET}_{\mathrm{o}, \mathrm{s}}$ and $\mathrm{ET}_{\mathrm{o}, \mathrm{i}}$ in different sub-regions and whole Bangladesh. 

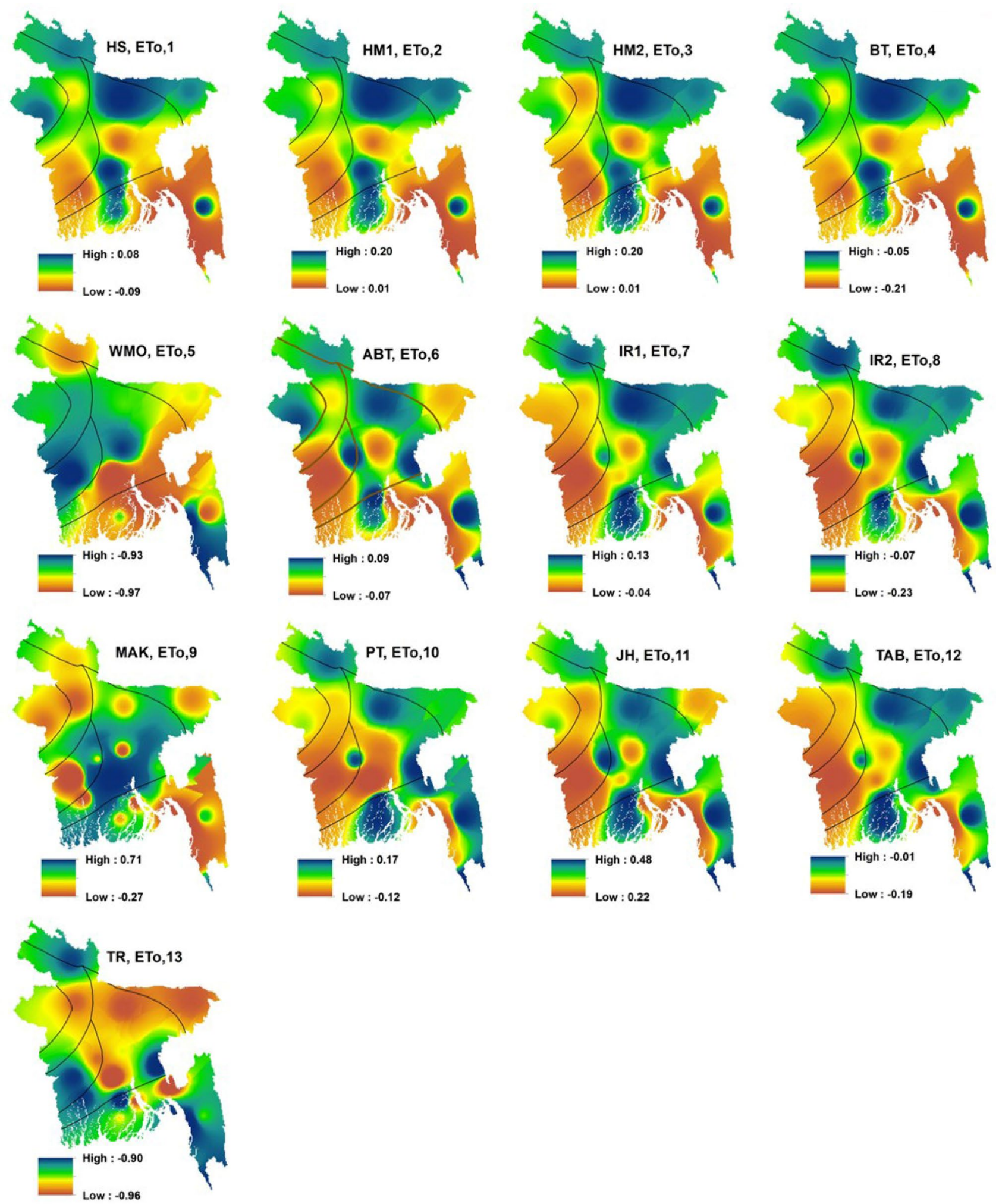

Figure 7. Spatial distribution of relative error values for multi-year mean monthly $\mathrm{ET}_{\mathrm{o}, \mathrm{i}}$ in Bangladesh, prepared by ArcGis 10.5 (www.esri.com). 


\begin{tabular}{|c|c|c|c|c|c|c|c|c|c|c|c|c|c|}
\hline $\mathrm{ET}_{\mathrm{o}, \mathrm{i}}$ & $\mathrm{ET}_{0,1}$ & $\mathrm{ET}_{0,2}$ & $\mathrm{ET}_{0,3}$ & $\mathrm{ET}_{0,4}$ & $\mathbf{E T}_{0,5}$ & $\mathrm{ET}_{0,6}$ & $\mathrm{ET}_{0,7}$ & $\mathrm{ET}_{0,8}$ & $\mathrm{ET}_{0,9}$ & $\mathrm{ET}_{0,10}$ & $\mathrm{ET}_{0,11}$ & $\mathrm{ET}_{0,12}$ & $\mathrm{ET}_{0,13}$ \\
\hline \multicolumn{14}{|c|}{ Month/year } \\
\hline Jan & 0.8428 & 0.6065 & 0.2472 & 1.2001 & 3.6024 & 0.6445 & 0.7391 & 1.2053 & 1.4635 & 1.2277 & 0.5630 & 1.2919 & 2.1696 \\
\hline Feb & 0.1778 & 0.2978 & 0.5039 & 0.5073 & 3.5384 & 0.1224 & 0.1562 & 0.5903 & 0.8282 & 0.3469 & 0.7474 & 0.6696 & 3.0446 \\
\hline Mar & 0.8772 & 1.2064 & 0.7722 & 0.3474 & 3.4644 & 0.5213 & 0.6215 & 0.1384 & 0.2671 & 0.7748 & 2.0732 & 0.1221 & 3.9983 \\
\hline Apr & 1.2023 & 1.6439 & 0.9778 & 0.5885 & 3.4517 & 0.1097 & 1.0133 & 0.3032 & 0.2066 & 1.5978 & 3.0151 & 0.4335 & 4.4995 \\
\hline May & 1439 & 1.6483 & 0.7211 & 0.5334 & 3.4982 & \begin{tabular}{|l|}
0.2788 \\
\end{tabular} & 0.9108 & 0.2805 & 2841 & 1.5718 & 2.8234 & 0.3941 & 4.2382 \\
\hline Jun & 5031 & 1.0590 & 0.3541 & 0.2434 & 3.5659 & 0.2386 & 0.4159 & 0.5439 & 7337 & 0.8229 & 1.7057 & 0.3194 & 3.3993 \\
\hline Jul & 0.3903 & 0.7151 & 0.3648 & 0.4633 & 3.5911 & 0.2045 & 0.3112 & 0.6522 & 0.8568 & 0.6409 & 1.4344 & 0.2689 & 3.1328 \\
\hline Aug & 0.3050 & 0.6421 & 0.5209 & 0.5180 & 3.5873 & 0.2181 & 0.3912 & 0.5703 & 0.7650 & 0.7311 & 1.6220 & 0.2223 & 3.2419 \\
\hline Sep & 0.2573 & 0.3774 & 0.5441 & 0.6840 & 3.5962 & 0.2237 & 0.2989 & 0.6237 & 0.8279 & 0.5066 & 1.4465 & 0.2449 & 3.0685 \\
\hline Oct & 0.4074 & 0.1889 & 0.6452 & 0.8218 & 3.5926 & 0.2847 & 0.3048 & 0.5850 & 0.7819 & 0.3394 & 1.4457 & 0.2989 & 2.9804 \\
\hline Nov & 0.6533 & 0.3651 & 0.4289 & 1.0397 & 3.5916 & 0.1981 & 0.2054 & 0.8368 & 1.0631 & 0.5793 & 0.6273 & 0.7131 & 2.5004 \\
\hline Dec & 0.9907 & 0.7483 & 0.2197 & 1.3340 & 3.6142 & 0.1554 & 0.7190 & 1.2593 & 1.5035 & 1.2897 & 0.5162 & 1.2602 & 2.0195 \\
\hline Year & 0.1045 & 0.4872 & 0.5062 & 0.4441 & 3.5580 & 0.0484 & 0.2064 & 0.5317 & 0.7337 & 0.2805 & 1.3012 & 0.3444 & 3.1848 \\
\hline
\end{tabular}

Table 2. Root Mean Square Error (RMSE) values of the 13 empirical models for calculating $\mathrm{ET}_{\mathrm{o}, \mathrm{i}}$ at the monthly and annual timescales for Bangladesh. The bold values indicate the optimal model among other models.

\begin{tabular}{|l|l|l|l|l|l|l|l|l|l|l|l|l|l|l|l|}
\hline $\mathbf{E T}_{\mathbf{0}, \mathbf{i}}$ & $\mathbf{E T}_{\mathbf{0 , 1}}$ & $\mathbf{E T}_{\mathbf{0}, \mathbf{2}}$ & $\mathbf{E T}_{\mathbf{0 , 3}}$ & $\mathbf{E T}_{\mathbf{0}, \mathbf{4}}$ & $\mathbf{E T}_{\mathbf{0}, \mathbf{5}}$ & $\mathbf{E T}_{\mathbf{0}, \mathbf{6}}$ & $\mathbf{E T}_{\mathbf{0}, \mathbf{7}}$ & $\mathbf{E T}_{\mathbf{0}, \mathbf{8}}$ & $\mathbf{E T}_{\mathbf{0 , 9}}$ & $\mathbf{E T}_{\mathbf{0}, \mathbf{1 0}}$ & $\mathbf{E T}_{\mathbf{0 , 1 1}}$ & $\mathbf{E T}_{\mathbf{0 , 1 2}}$ & $\mathbf{E T}_{\mathbf{0 , 1 3}}$ \\
\hline Month/year \\
\hline Jan & 0.398 & 0.562 & 0.222 & 0.273 & 2.497 & $\mathbf{0 . 2 6 0}$ & 0.425 & 0.251 & 0.384 & 0.256 & 0.613 & 0.264 & 2.163 \\
\hline Feb & 0.369 & 0.716 & 0.489 & 0.387 & 3.363 & $\mathbf{0 . 2 9 3}$ & 0.306 & 0.416 & 0.643 & 0.309 & 0.879 & 0.491 & 3.039 \\
\hline Mar & 0.361 & 0.471 & 0.760 & 0.601 & 4.296 & $\mathbf{0 . 3 2 0}$ & 0.336 & 0.884 & 1.063 & 0.389 & 1.232 & 0.866 & 3.992 \\
\hline Apr & 0.443 & 0.470 & 0.952 & 0.831 & 4.814 & $\mathbf{0 . 3 3 0}$ & 0.411 & 1.095 & 1.222 & 0.488 & 1.640 & 0.954 & 4.491 \\
\hline May & 0.374 & 0.605 & 0.694 & 0.646 & 4.591 & $\mathbf{0 . 3 1 5}$ & 0.314 & 1.000 & 1.137 & 0.575 & 1.681 & 0.770 & 4.227 \\
\hline Jun & 0.350 & 0.810 & 0.318 & 0.415 & 3.794 & $\mathbf{0 . 2 3 1}$ & 0.244 & 0.736 & 0.930 & 0.593 & 1.428 & 0.366 & 3.391 \\
\hline Jul & 0.305 & 0.742 & 0.320 & 0.457 & 3.546 & $\mathbf{0 . 1 8 7}$ & 0.309 & 0.578 & 0.786 & 0.651 & 1.430 & 0.200 & 3.125 \\
\hline Aug & 0.285 & 0.557 & 0.493 & 0.575 & 3.657 & $\mathbf{0 . 1 9 0}$ & 0.297 & 0.600 & 0.800 & 0.644 & 1.503 & 0.220 & 3.235 \\
\hline Sep & 0.287 & 0.473 & 0.521 & 0.581 & 3.490 & $\mathbf{0 . 1 7 4}$ & 0.381 & 0.503 & 0.707 & 0.599 & 1.524 & 0.164 & 3.063 \\
\hline Oct & 0.283 & 0.340 & 0.631 & 0.615 & 3.394 & $\mathbf{0 . 2 9 6}$ & 0.468 & 0.359 & 0.555 & 0.505 & 1.600 & 0.167 & 2.974 \\
\hline Nov & 0.280 & 0.436 & 0.413 & 0.365 & 2.880 & $\mathbf{0 . 3 3 6}$ & 0.584 & 0.213 & 0.356 & 0.288 & 1.281 & 0.204 & 2.496 \\
\hline Dec & 0.366 & 0.538 & 0.196 & 0.244 & 2.370 & $\mathbf{0 . 2 6 2}$ & 0.565 & 0.232 & 0.296 & 0.232 & 0.819 & 0.221 & 2.013 \\
\hline Year & 0.226 & 0.500 & 0.500 & 0.448 & 3.557 & $\mathbf{0 . 1 7 8}$ & 0.244 & 0.528 & 0.731 & 0.343 & 1.299 & 0.341 & 3.183 \\
\hline
\end{tabular}

Table 3. Mean Absolute Error (MAE) values of 13 empirical models for calculating $\mathrm{ET}_{\mathrm{o}, \mathrm{i}}$ at the monthly and annual timescales for Bangladesh. The bold values indicate the optimal model among other models.

\begin{tabular}{|c|c|c|c|c|c|c|c|c|c|c|c|c|c|}
\hline $\mathrm{ET}_{\mathrm{o}, \mathrm{i}}$ & $\mathrm{ET}_{0,1}$ & $\mathrm{ET}_{0,2}$ & $\mathbf{E T}_{0,3}$ & $\mathrm{ET}_{0,4}$ & $\mathrm{ET}_{0,5}$ & $\mathrm{ET}_{0,6}$ & \begin{tabular}{|l|}
$\mathbf{E T}_{0,7}$ \\
\end{tabular} & $\mathrm{ET}_{0,8}$ & $\mathrm{ET}_{0,9}$ & $\mathrm{ET}_{0,10}$ & $\mathrm{ET}_{0,11}$ & $\mathrm{ET}_{0,12}$ & $\mathrm{ET}_{0,13}$ \\
\hline \multicolumn{14}{|c|}{ Month/year } \\
\hline Jan & -0.274 & -1.258 & -1.033 & 0.123 & -35.578 & 0.255 & -0.39 & 0.354 & -0.302 & 0.336 & -1.958 & 0.258 & -155.576 \\
\hline Feb & -0.103 & -2.353 & -5.205 & -0.426 & -58.766 & 0.238 & 0.312 & -0.449 & -1.77 & 0.166 & -3.821 & -0.828 & -225.502 \\
\hline Mar & -0.093 & -0.559 & -9.619 & -1.523 & -89.31 & 0.142 & 0.003 & -3.595 & -5.338 & -0.23 & -7.404 & -3.525 & -283.656 \\
\hline Apr & -0.065 & -0.089 & -10.441 & -1.993 & -74.489 & 0.362 & -0.061 & -3.579 & -4.554 & -0.105 & -8.519 & -2.672 & -241.254 \\
\hline May & 0.187 & -0.754 & -4.042 & -1.022 & -72.584 & 0.354 & 0.338 & -3.021 & -4.07 & -0.452 & -9.741 & -1.603 & -173.139 \\
\hline Jun & -0.127 & -3.507 & -1.077 & -0.462 & -81.971 & 0.38 & 0.467 & -2.519 & -4.436 & -1.483 & -11.67 & -0.159 & -190.445 \\
\hline Jul & -0.495 & -5.005 & -1.591 & -1.531 & -109.474 & 0.436 & -0.093 & -2.268 & -4.824 & -3.206 & -17.811 & 0.422 & -190.097 \\
\hline Aug & -0.233 & -2.778 & -4.285 & -2.871 & -121.219 & 0.351 & -0.03 & -2.678 & -5.35 & -3.301 & -20.738 & 0.263 & -203.639 \\
\hline Sep & -0.415 & -2.248 & -7.579 & -3.418 & -124.944 & 0.419 & -0.781 & -1.972 & -4.612 & -3.229 & -23.887 & 0.48 & -271.754 \\
\hline Oct & -0.481 & -0.762 & -9.322 & -3.902 & -119.488 & -0.355 & -1.729 & -0.846 & -2.843 & -2.18 & -26.957 & 0.439 & -219.231 \\
\hline Nov & -0.309 & -1.496 & -7.088 & -1.192 & -82.924 & -0.672 & -2.958 & 0.103 & -0.97 & -0.236 & -16.758 & 0.266 & -273.802 \\
\hline Dec & -0.371 & -1.721 & -0.683 & 0.106 & -42.958 & 0.047 & -1.95 & 0.255 & -0.226 & 0.281 & -5.249 & 0.311 & -141.118 \\
\hline Year & -0.477 & -4.116 & -25.07 & -3.474 & -211.012 & 0.176 & -0.341 & -4.411 & -8.788 & -1.498 & -28.244 & -1.667 & -1030.942 \\
\hline
\end{tabular}

Table 4. Nash-Sutcliffe efficiency (NSE) coefficients of the 13 empirical models for calculating $\mathrm{ET}_{\mathrm{o}, \mathrm{i}}$ at the monthly and annual timescales for Bangladesh. The bold values indicate the optimal model among other models. 


\begin{tabular}{|l|r|l|l|l|l|l|l|l|l|l|l|l|l|l|l|}
\hline $\mathbf{E T}_{\mathbf{0}, \mathbf{i}}$ & $\mathbf{E T}_{\mathbf{0}, \mathbf{1}}$ & $\mathbf{E T}_{\mathbf{0}, \mathbf{2}}$ & $\mathbf{E T}_{\mathbf{0}, \mathbf{3}}$ & $\mathbf{E T}_{\mathbf{0}, \mathbf{4}}$ & $\mathbf{E T}_{\mathbf{0}, \mathbf{5}}$ & $\mathbf{E T}_{\mathbf{0}, \mathbf{6}}$ & $\mathbf{E T}_{\mathbf{0}, \mathbf{7}}$ & $\mathbf{E T}_{\mathbf{0}, \mathbf{8}}$ & $\mathbf{E T}_{\mathbf{0}, \mathbf{9}}$ & $\mathbf{E T}_{\mathbf{0}, \mathbf{1 0}}$ & $\mathbf{E T}_{\mathbf{0 , 1 1}}$ & $\mathbf{E T}_{\mathbf{0}, \mathbf{1 2}}$ & $\mathbf{E T}_{\mathbf{0}, 13}$ \\
\hline \multicolumn{1}{|l|}{ Month/year } \\
\hline Jan & 0.271 & 0.509 & -0.222 & -0.090 & -2.497 & $-\mathbf{0 . 0 2 5}$ & 0.380 & -0.091 & -352 & -0.118 & 0.591 & -0.181 & -2.163 \\
\hline Feb & 0.153 & 0.654 & -0.489 & -0.307 & -3.363 & $\mathbf{0 . 0 0 2}$ & 0.138 & -0.398 & -0.640 & -0.129 & 0.871 & -0.482 & -3.039 \\
\hline Mar & 0.011 & 0.354 & 0.787 & -0.561 & -4.296 & $-\mathbf{0 . 0 4 3}$ & -0.225 & -0.883 & -1.063 & -0.073 & 1.225 & -0.865 & -3.995 \\
\hline Apr & -0.179 & 0.269 & 0.945 & -0.806 & -4.814 & $-\mathbf{0 . 0 2 4}$ & -0.360 & -1.094 & -1.222 & 0.224 & 1.636 & -0.952 & -4.498 \\
\hline May & 0.025 & 0.540 & 0.690 & -0.603 & -4.591 & $-\mathbf{0 . 0 0 9}$ & -0.213 & -0.999 & -1.137 & 0.438 & 1.679 & -0.767 & -4.230 \\
\hline Jun & 0.215 & 0.805 & 0.315 & -0.346 & -3.794 & $-\mathbf{0 . 1 0 1}$ & 0.137 & -0.731 & -0.927 & 0.542 & 1.427 & -0.343 & -3.397 \\
\hline Jul & 0.129 & 0.740 & 0.311 & -0.392 & -3.546 & $-\mathbf{0 . 0 8}$ & 0.294 & -0.578 & -0.786 & 0.628 & 1.430 & -0.153 & -3.120 \\
\hline Aug & -0.043 & 0.541 & 0.482 & -0.555 & -3.657 & $-\mathbf{0 . 0 5 0}$ & 0.268 & -0.600 & -0.800 & 0.604 & 1.503 & -0.187 & -3.230 \\
\hline Sep & -0.081 & 0.442 & 0.531 & -0.559 & -3.490 & $\mathbf{0 . 0 4 3}$ & 0.370 & -0.500 & -0.707 & 0.574 & 1.524 & -0.100 & -3.055 \\
\hline Oct & -0.161 & 0.254 & 0.625 & -0.605 & -3.394 & $\mathbf{0 . 2 1 8}$ & 0.444 & -0.351 & -0.554 & 0.454 & 1.600 & -0.051 & -2.956 \\
\hline Nov & 0.074 & 0.371 & 0.421 & -0.320 & -2.880 & $\mathbf{0 . 2 6 1}$ & 0.572 & -0.109 & -0.338 & 0.154 & 1.280 & 0.013 & -2.356 \\
\hline Dec & 0.258 & 0.502 & 0.187 & -0.087 & -2.370 & $\mathbf{0 . 1 0 7}$ & 0.546 & -0.002 & -0.249 & -0.038 & 0.804 & -0.006 & -2.113 \\
\hline Year & 0.056 & 0.480 & -0.500 & -0.436 & -3.557 & $\mathbf{0 . 0 2 5}$ & 0.198 & -0.528 & -0.731 & 0.274 & 1.299 & -0.338 & -3.283 \\
\hline
\end{tabular}

Table 5. Mean Bias Error (MBE) values of the 13 empirical models for calculating $\mathrm{ET}_{\mathrm{o}, \mathrm{i}}$ at the monthly and annual timescales for Bangladesh. The bold values indicate the optimal model among other models.

$\mathrm{MBE}$ at both long term annual and monthly time scale in calculating $\mathrm{ET}_{\mathrm{o}, \mathrm{i}}$ in Bangladesh is shown in Table 5. $\mathrm{ET}_{\mathrm{o}, 6}$ and $\mathrm{ET}_{\mathrm{o}, 1}$ showed higher performance accuracy, producing lower MBE values. Again, $\mathrm{ET}_{\mathrm{o}, 5} ; \mathrm{ET}_{\mathrm{o}, 13}$ and $\mathrm{ET}_{\mathrm{o}, 11}$ models showed the least performance accuracy for calculating $\mathrm{ET}_{\mathrm{o}, \mathrm{i}}$. Other models showed moderate performance accuracy in estimating $\mathrm{ET}_{\mathrm{o}, \mathrm{i}}$. From the above discussions of performance accuracy, $\mathrm{ET}_{\mathrm{o}, 6}$ revealed as the suitable alternative model for estimating ETo in Bangladesh. Whereas, $\mathrm{ET}_{0,5} ; \mathrm{ET}_{0,13}$ and $\mathrm{ET}_{0,11}$ models explored as the worst performed empirical models inappropriate for estimating $\mathrm{ET}_{\mathrm{o}}$ in Bangladesh. Figure 8 shows the scatter plots of daily $\mathrm{ET}_{\mathrm{o}, \mathrm{s}} \mathrm{vs} . \mathrm{ET}_{\mathrm{o}, \mathrm{i}}$ of Bangladesh during 1980-2017. The $\mathrm{ET}_{\mathrm{o}, 6} ; \mathrm{ET}_{\mathrm{o}, 7}$ and $\mathrm{ET}_{\mathrm{o}, 11}$ models outperformed among 13 empirical models with higher $\mathrm{r}$-value (0.92). $\mathrm{ET}_{\mathrm{o}, 10}$ (r-value 0.91) and $\mathrm{ET}_{\mathrm{o}, 12}$ (r-value 0.90) performed well, respectively, which produced r-values $\geq 0.90$.

All the scatter plots produced $r$ values with significant $\mathrm{p}$-value $(<0.05)$ indicating a strong correlation between $\mathrm{ET}_{\mathrm{o}, \mathrm{s}}$ and $\mathrm{ET}_{\mathrm{o}, \mathrm{i}}$. Among 13 empirical models, $\mathrm{ET}_{\mathrm{o}, 5}$ recognized as the worst model with a lower accuracy and reliability than other models as this model produced the $r$-value of 0.78 which is less than 0.80 . From the comparisons of 13 empirical models by RE, RMSE, MAE, NSE, MBE and scatter plots, $\mathrm{ET}_{0,6}$ model found as the best suitable alternative model against the $\mathrm{ET}_{\mathrm{o}, \mathrm{s}}$ model for calculating ETo for all the sub-regions and whole Bangladesh.

Exploring the most suitable model for $\mathrm{ET}_{\mathrm{o}}$ computation using the RF algorithm. The importance degree analysis of the empirical models was calculated by the RF method at different sub-regions of Bangladesh. The RF model depicted a suitable significant model followed by other analyses against the FAO56-PM model for all of the sub-regions (Table 6). The best performed model is highlighted by bold face and the least performed model is marked by italic face (Table 6) for estimating ETo. As can be seen from Table 6, the $\mathrm{ET}_{\mathrm{o}, 6}$ outperformed for ETo estimation in all the sub-regions of Bangladesh as it produced a comparatively higher importance degree. Whereas, $\mathrm{ET}_{0,5}$ found as the worst model producing the lowest importance degree among all the models.

Validation of the best alternative model for $\mathrm{ET}_{\mathrm{o,s} \mathbf{s}^{*}} \quad$ Validation is very important for determining the most suitable model from several potential models. All the applied empirical models need to validate to ensure whether the pre-analyses gave the accurate results or not and to find the best suitable alternative empirical model against the FAO56-PM. Validation was undertaken by utilizing the linear correlation method. Following Peng et al. $^{11}$, the linear correlation was calculated by the below Eq. (33):

$$
E T_{o, s}=\frac{E T_{o, i}-b}{a}
$$

where, $a$ and $b$ denoted as fitted coefficients.

Table 7 shows the fitted $a, b$ and $\mathrm{R}^{2}$ values of correlation between $\mathrm{ET}_{\mathrm{o}, \mathrm{s}}$ and $\mathrm{ET}_{\mathrm{o}, \mathrm{i}}$ in seven sub-regions and whole Bangladesh. A strong correlation between $\mathrm{ET}_{\mathrm{o}, \mathrm{s}}$ and $\mathrm{ET}_{\mathrm{o}, \mathrm{i}}$ was found in all sub-regions and whole Bangladesh. Values of $\mathrm{R}^{2}$ is greater than 0.8 in every sub-regions and in whole Bangladesh for all the 13 empirical models indicating a strong correlation between $\mathrm{ET}_{\mathrm{o}, \mathrm{s}}$ and $\mathrm{ET}_{\mathrm{o}, \mathrm{i}}$. The model which is highly correlated with the $\mathrm{ET}_{\mathrm{o}, \mathrm{s}}$ is highlighted with light pink color. Among 13 models $\mathrm{ET}_{\mathrm{o}, 6}$ performed best, producing greater $\mathrm{R}^{2}$ values than the other models. $\mathrm{ET}_{0,6}$ model is simple among all the models used in this study as this model utilized only Tmax and Rs. Rs is calculated from $\mathrm{T}_{\max }$ and $\mathrm{T}_{\min }$. $\mathrm{T}_{\max }$ and $\mathrm{T}_{\min }$ are available everywhere in each region and can estimate easily. So, it can be affirmed that the $\mathrm{ET}_{0,6}$ is the best suitable, preferred, accurate, simple and reliable model, highly consisted with the results of pre-analyses (spatial and temporal distribution, performance evaluation and importance degree analysis), for ETo estimation in all the sub-regions and whole Bangladesh. 

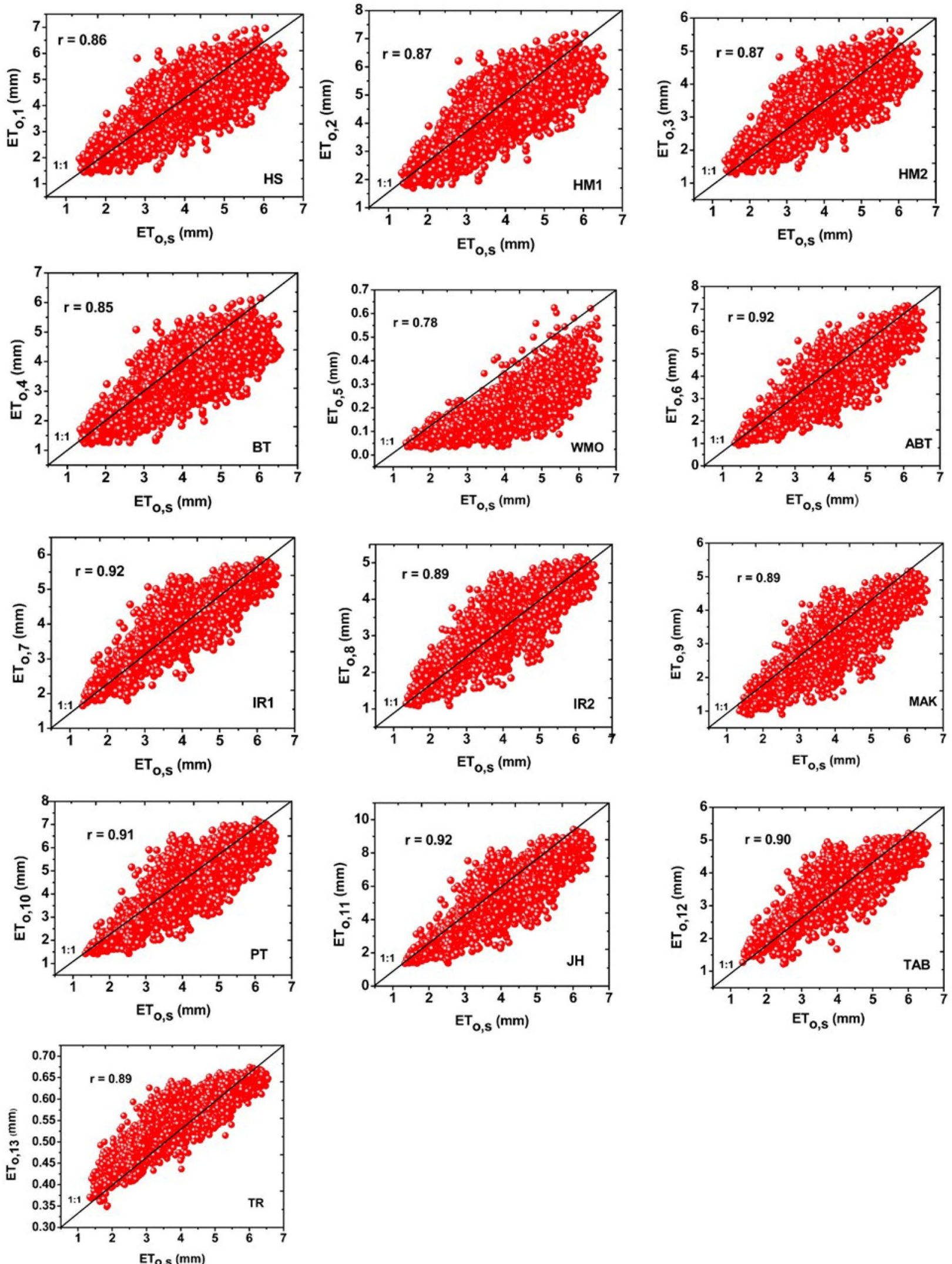

Figure 8. Scatter plots showing the comparisons of daily $\mathrm{ET}_{\mathrm{o}, \mathrm{i}}$ and $\mathrm{ET}_{\mathrm{o}, \mathrm{s}}$ in Bangladesh. 


\begin{tabular}{|l|c|c|l|c|l|l|l|}
\hline Models & I & II & III & IV & V & VI & VII \\
\hline $\mathrm{ET}_{0,1}$ & 4.27 & 6.27 & 9.03 & 2.22 & 2.46 & 5.10 & 5.07 \\
\hline $\mathrm{ET}_{0,2}$ & 3.99 & 6.16 & 4.34 & 2.34 & 5.81 & 5.81 & 4.87 \\
\hline $\mathrm{ET}_{0,3}$ & 9.02 & 7.27 & 5.61 & 2.51 & 5.15 & 5.15 & 4.87 \\
\hline $\mathrm{ET}_{0,4}$ & 7.46 & 6.57 & 7.53 & 5.00 & 9.47 & 2.71 & 4.45 \\
\hline $\mathrm{ET}_{0,5}$ & 3.78 & 2.69 & 3.57 & 2.12 & 2.71 & 2.46 & 4.14 \\
\hline $\mathrm{ET}_{0,6}$ & $\mathbf{1 6 . 0 0}$ & $\mathbf{2 4 . 6 5}$ & $\mathbf{2 6 . 7 0}$ & $\mathbf{2 3 . 5 7}$ & $\mathbf{2 8 . 2 3}$ & $\mathbf{2 8 . 2 3}$ & $\mathbf{1 9 . 6 1}$ \\
\hline $\mathrm{ET}_{0,7}$ & 8.70 & 8.14 & 7.01 & 7.68 & 5.10 & 9.47 & 8.65 \\
\hline $\mathrm{ET}_{0,8}$ & 9.38 & 7.99 & 7.48 & 9.98 & 9.55 & 9.55 & 8.91 \\
\hline $\mathrm{ET}_{0,9}$ & 8.37 & 8.43 & 5.40 & 8.51 & 6.00 & 6.00 & 6.11 \\
\hline $\mathrm{ET}_{0,10}$ & 8.36 & 8.74 & 7.95 & 8.30 & 7.78 & 7.78 & 6.96 \\
\hline $\mathrm{ET}_{0,11}$ & 8.81 & 6.48 & 7.05 & 11.05 & 8.98 & 8.98 & 8.89 \\
\hline $\mathrm{ET}_{0,12}$ & 7.90 & 3.85 & 4.84 & 10.30 & 2.91 & 2.91 & 10.90 \\
\hline $\mathrm{ET}_{0,13}$ & 3.97 & 2.76 & 3.46 & 6.44 & 5.85 & 5.85 & 6.58 \\
\hline
\end{tabular}

Table 6. Importance degree of 13 empirical models against FAO56-PM model in seven sub-regions in Bangladesh using RF model. Bold face indicates the highest importance degree while italic face denotes the least importance degree.

\begin{tabular}{|c|c|c|c|c|c|c|c|c|c|c|c|c|c|c|}
\hline Sub-region & Parameter & $\mathrm{ET}_{0,1}$ & $\mathrm{ET}_{0,2}$ & $\mathrm{ET}_{0,3}$ & $\mathrm{ET}_{0,4}$ & $\mathrm{ET}_{0,5}$ & $\mathrm{ET}_{0,6}$ & $\mathrm{ET}_{0,7}$ & $\mathrm{ET}_{0,8}$ & $\mathbf{E T}_{0,9}$ & $\mathrm{ET}_{0,10}$ & $\mathrm{ET}_{0,11}$ & $\mathrm{ET}_{0,12}$ & $\mathbf{E T}_{0,13}$ \\
\hline \multirow{3}{*}{ I } & A & 0.738 & 0.761 & 0.435 & 0.645 & 0.058 & 1.089 & 0.712 & 0.697 & 0.760 & 1.151 & 1.479 & 0.683 & 0.089 \\
\hline & B & 0.954 & 1.229 & 1.559 & 0.815 & 0.045 & -0.312 & 1.292 & 0.619 & 0.196 & 0.215 & -0.458 & 0.879 & \begin{tabular}{|l|}
0.078 \\
\end{tabular} \\
\hline & $\mathrm{R}^{2}$ & 0.901 & 0.919 & 0.911 & 0.978 & 0.917 & 0.989 & 0.988 & 0.986 & 0.984 & 0.986 & 0.984 & \begin{tabular}{|l|}
0.988 \\
\end{tabular} & 0.921 \\
\hline \multirow{3}{*}{ II } & A & 0.781 & 0.794 & 0.787 & \begin{tabular}{|l|}
0.688 \\
\end{tabular} & 0.055 & 1.076 & 0.694 & 0.702 & 0.754 & 1.038 & 1.393 & 0.641 & 0.078 \\
\hline & $\mathrm{B}$ & 0.934 & 1.310 & 1.222 & 0.782 & 0.040 & -0.259 & 1.335 & 0.608 & 0.225 & 0.155 & -0.188 & 1.003 & 0.045 \\
\hline & $\mathrm{R}^{2}$ & 0.958 & 0.96 & 0.942 & 0.956 & 0.86 & 0.982 & 0.98 & 0.982 & 0.98 & 0.974 & 0.978 & \begin{tabular}{|l|}
0.98 \\
\end{tabular} & 0.88 \\
\hline \multirow{3}{*}{ III } & A & 0.744 & 0.782 & 0.752 & 0.651 & 0.054 & 1.032 & 0.695 & 0.667 & 0.716 & 1.051 & 1.38 & 0.656 & 0.067 \\
\hline & B & 1.061 & 1.333 & 1.342 & 0.908 & 0.045 & -0.049 & 1.351 & 0.760 & 0.395 & 0.163 & -0.070 & 0.956 & 0.055 \\
\hline & $\mathrm{R}^{2}$ & 0.956 & 0.96 & 0.961 & 0.955 & 0.848 & 0.988 & 0.976 & 0.987 & 0.974 & 0.974 & 0.974 & 0.974 & 0.854 \\
\hline \multirow{3}{*}{ IV } & $\mathrm{A}$ & 0.713 & 0.747 & 0.735 & 0.624 & 0.060 & 1.051 & 0.694 & 0.675 & 0.727 & 1.051 & 1.401 & 0.660 & 0.079 \\
\hline & $\mathrm{B}$ & 1.154 & 1.435 & 1.255 & 0.990 & 0.050 & -0.162 & 1.306 & 0.660 & 0.279 & 0.062 & -0.236 & 0.894 & 0.058 \\
\hline & $\mathrm{R}^{2}$ & 0.943 & 0.951 & 0.964 & 0.941 & 0.856 & 0.984 & 0.978 & 0.978 & 0.978 & 0.976 & 0.976 & 0.978 & 0.861 \\
\hline \multirow{3}{*}{ V } & A & 0.782 & 0.805 & 0.741 & 0.687 & 0.071 & 1.000 & 0.631 & 0.591 & 0.644 & 0.953 & 1.302 & 0.582 & 0.085 \\
\hline & B & 1.006 & 1.315 & 1.233 & 0.856 & 0.097 & 0.099 & 1.564 & 1.012 & 0.628 & 0.457 & 0.179 & 1.179 & 0.099 \\
\hline & $\mathrm{R}^{2}$ & 0.956 & 0.962 & 0.967 & 0.955 & 0.803 & 0.974 & 0.972 & 0.970 & 0.970 & 0.970 & 0.972 & 0.968 & 0.812 \\
\hline \multirow{3}{*}{ VI } & $\mathrm{A}$ & 0.619 & 0.643 & 0.687 & 0.543 & 0.083 & 0.817 & 0.520 & 0.493 & 0.538 & 0.813 & 1.084 & 0.488 & 0.098 \\
\hline & B & 1.504 & 1.819 & 1.612 & 1.295 & 0.115 & 0.566 & 1.868 & 1.233 & 0.866 & 0.833 & 0.751 & 1.424 & 0.122 \\
\hline & $\mathrm{R}^{2}$ & 0.955 & 0.956 & 0.954 & 0.952 & 0.866 & 0.978 & 0.964 & 0.966 & 0.966 & 0.968 & 0.970 & 0.964 & 0.871 \\
\hline \multirow{3}{*}{ VII } & $\mathrm{A}$ & 0.744 & 0.799 & 0.778 & 0.649 & 0.052 & 0.995 & 0.67 & 0.626 & 0.663 & 1.023 & 1.363 & 0.646 & 0.056 \\
\hline & $\mathrm{B}$ & 1.091 & 1.306 & 1.124 & 0.943 & 0.033 & 0.097 & 1.455 & 0.882 & 0.493 & 0.107 & 0.009 & 0.994 & 0.043 \\
\hline & $\mathrm{R}^{2}$ & 0.968 & 0.972 & 0.952 & 0.966 & \begin{tabular}{|l|}
0.914 \\
\end{tabular} & \begin{tabular}{|l|}
0.979 \\
\end{tabular} & \begin{tabular}{|l|}
0.98 \\
\end{tabular} & 0.976 & 0.974 & 0.976 & 0.974 & \begin{tabular}{|l|}
0.98 \\
\end{tabular} & 0.911 \\
\hline \multirow{3}{*}{ Whole BD } & A & 0.796 & 0.846 & 0.784 & 0.696 & 0.061 & 1.046 & 0.654 & 0.691 & 0.706 & 1.098 & 1.418 & \begin{tabular}{|l|}
0.660 \\
\end{tabular} & 0.071 \\
\hline & B & 0.818 & 1.054 & 1.102 & \begin{tabular}{|l|}
0.699 \\
\end{tabular} & 0.056 & -0.151 & 0.763 & 1.348 & 0.363 & -0.091 & -0.258 & \begin{tabular}{|l|}
0.929 \\
\end{tabular} & 0.057 \\
\hline & $\mathrm{R}^{2}$ & 0.743 & 0.766 & \begin{tabular}{|l|}
0.787 \\
\end{tabular} & 0.736 & \begin{tabular}{|l|}
0.615 \\
\end{tabular} & 0.856 & \begin{tabular}{|l|}
0.803 \\
\end{tabular} & 0.849 & 0.811 & 0.843 & 0.851 & \begin{tabular}{|l|}
0.825 \\
\end{tabular} & \begin{tabular}{|l|}
0.601 \\
\end{tabular} \\
\hline
\end{tabular}

Table 7. Fitted $a, b$ and $\mathrm{R}^{2}$ values of correlation between $\mathrm{ET}_{\mathrm{o}, \mathrm{s}}$ and $\mathrm{ET}_{\mathrm{o}, \mathrm{i}}$ in seven sub-regions and whole Bangladesh.

\section{Discussions}

Increasing and decreasing as well as significant and non-significant trends were found across the country from 1980 to 2017. The rates between increasing and decreasing of $\mathrm{ET}_{\mathrm{o}, \mathrm{s}}$ was 72.18 to $-72.17 \mathrm{~mm}$ per decade in this study. For example, Bhola, Cumilla, Feni, Rangamati and Patuakhali showed a significant increasing trend of $\mathrm{ET}_{\mathrm{o}, \mathrm{s}}$ and nonsignificant decreasing trend of $\mathrm{ET}_{\mathrm{o}, \mathrm{s}}$ found in Faridpur, Madaripur, Dhaka and Barishal of sub-regions I and VII (southeastern and south-central regions). The significant decreasing trend of $\mathrm{ET}_{\mathrm{o}, \mathrm{s}}$ showed by the sub-regions of II, III, IV and V. Cox's Bazar, Teknaf, Sandwip, Chattogram, Jashore, Mymensingh and Khulna showed a significant decreasing trend of $\mathrm{ET}_{\mathrm{o}, \mathrm{s}}$. From the above results, it is evident that the trend of $\mathrm{ET}_{\mathrm{o}, \mathrm{s}}$ was decreasing gradually in Bangladesh 
from 1980 to 2017. Rahman et al. ${ }^{15}$ found that most of the area of Bangladesh showed decreasing trends and some parts of the study area showed an increasing trend of $\mathrm{ET}_{\mathrm{o}, \mathrm{s}}$ which is analogous to the results of this study. Decreasing the trend of $\mathrm{ET}_{\mathrm{o}, \mathrm{s}}$ may be the results of worldwide climate change impacts. Spatial distribution of the long-term mean monthly between $\mathrm{ET}_{\mathrm{o}, \mathrm{s}}$ and $\mathrm{ET}_{\mathrm{o}, 6}$ (Abtew) in Bangladesh shown a homogenous pattern. By contrary, $\mathrm{ET}_{\mathrm{o}, 5}(\mathrm{WMO})$ and $\mathrm{ET}_{\mathrm{o}, 13}$ (Turc) models produced the least close values to $\mathrm{ET}_{\mathrm{o}, \mathrm{s}}$ in terms of spatial distribution. Temporal distribution of long-term monthly $\mathrm{ET}_{\mathrm{o}, \mathrm{s}}$, and $\mathrm{ET}_{\mathrm{o}, \mathrm{i}}$ in Bangladesh found that the highest and lowest rate of ETo occurred in April and January-December, respectively. Peng et al. ${ }^{11}$ and $\mathrm{Li}$ et al. ${ }^{24}$ showed that the highest and lowest rate of $\mathrm{ET}_{\mathrm{o}, \mathrm{s}}$ occurred in China in July (dissimilar to this study) and January-December which is similar to this study. Long term inter-annual variation of $\mathrm{ET}_{\mathrm{o}, \mathrm{s}}$, and $\mathrm{ET}_{\mathrm{o}, \mathrm{i}}$ in Bangladesh revealed that $\mathrm{ET}_{\mathrm{o}, 5}$ and $\mathrm{ET}_{\mathrm{o}, 13}$ models produced very lower values, identifying the least performed method for calculating ETo. Previous studies ${ }^{5,11,24,29}$ along with this study revealed that ETo values obtained by both $\mathrm{ET}_{\mathrm{o}, \mathrm{s}}$ and $\mathrm{ET}_{\mathrm{o}, \mathrm{i}}$ models were very closer to each other in the month of January-December (cold season) and highest discrepancy occurred among them in the hot summer season.

Long term monthly RE (relative error) of $\mathrm{ET}_{\mathrm{o}, \mathrm{i}}$ revealed that the WMO and Turc models were the least suitable with greater RE values and Abtew model was an optimal alternative with lower RE values against the FAO56-PM for calculating ETo in Bangladesh. The values of RMSE, MAE, NSE, and MBE had the strong concurrence with the RE exploring the same results as Abtew $\left(\mathrm{ET}_{\mathrm{o}, 6}\right)$ was the best alternative and WMO $\left(\mathrm{ET}_{\mathrm{o}, 5}\right)$; Turc $\left(\mathrm{ET}_{\mathrm{o}, 13}\right)$ were the least suitable model for estimating ETo in Bangladesh. Gabriela and Irmak ${ }^{73}$ evaluated the impact of the meteorological variables on the estimates of 13 empirical models in various regions and found that the Doorenbos and Pruitt $\left(\mathrm{ET}_{\mathrm{o}, 12}\right)$ ranked top in the three regions of Iran under sub-humid to sub-arid climate conditions which are in disagreement with the results of this study. Identification of the best suitable model against $\mathrm{ET}_{\mathrm{o}, \mathrm{s}}$ varies from region to region and country to country. It might be due to the variation of geographical and meteorological variations from one country to another country and input model combinations. Correlation between long term daily $\mathrm{ET}_{\mathrm{o}, \mathrm{s}}$ and $\mathrm{ET}_{\mathrm{o}, \mathrm{i}}$ in Bangladesh was explored that a very strong correlation aligns with no one line (1:1) existed between $\mathrm{ET}_{\mathrm{o}, \mathrm{s}}$ and $\mathrm{ET}_{\mathrm{o}, 6}$ (Abtew) with the $\mathrm{r}$ values of 0.92 . Li et al. ${ }^{24}$ also found a strong correlation $\left(\mathrm{R}^{2}\right.$ was 0.972 ) between daily $\mathrm{ET}_{\mathrm{o}, \mathrm{s}}$ and $\mathrm{ET}_{\mathrm{o}, 13}$ (Valiantzas 3 ) in China. Xystrakis and Matzarakis ${ }^{35}$ found a strong correlation (r-value 0.993) between monthly $\mathrm{ET}_{\mathrm{o}, \mathrm{s}}$, and $\mathrm{ET}_{\mathrm{o}, \mathrm{i}}(\mathrm{Turc})$ in Greece. There also existed a strong correlation (r-value 0.996 ) between $\mathrm{ET}_{\mathrm{o}, \mathrm{s}}$, and $\mathrm{ET}_{\mathrm{o}, \mathrm{i}}$ (Blaney-Criddle) explored by Tabari et al. ${ }^{40}$ in Iran. Peng et al. ${ }^{11}$ found the largest correlation between monthly $\mathrm{ET}_{\mathrm{o}, \mathrm{s}}$, and $\mathrm{ET}_{\mathrm{o}, 6}{ }^{53}$ in China. Present study found the Abtew $\left(\mathrm{ET}_{\mathrm{o}, 6}\right)$ model as the most reliable model for estimating ETo, compared to the other empirical models in all the sub-regions of Bangladesh, as this model produced a higher importance degree.

Evaluation of the performance of different empirical models for estimating the $\mathrm{ET}_{\mathrm{o}, \mathrm{s}}$ was finally validated by Eq. (33). This study explored that Abtew $\left(\mathrm{ET}_{\mathrm{o}, 6}\right)$ model outperformed other models with $\mathrm{R}^{2}$ values ranged from 0.856 to 0.989 at all the sub-regions of Bangladesh. This is in good agreement with the earlier performance appraisal results in which RMSE, MAE, MBE, and NSE are the lowest in $\mathrm{ET}_{0,6}$ model. The main reason is that this model has high precision, easy, consistent; requiring less climatic datasets and strong association with FAO56PM. This model provides satisfactory outcomes and generally uses simple computable parameters and has easy model forms. Djaman et al. ${ }^{33}$ also found a similar result as this study that the Abtew was the best alternative model against the FAO56-PM in New Mexico, USA. Li et al. ${ }^{24}$ found Valiantzas 3 as the outperformed model among 13 empirical models for estimating ETo with $\mathrm{R}^{2}$ values ranged from 0.882 to 0.993 . Peng et al. ${ }^{11}$ explored $\mathrm{ET}_{\mathrm{o}, 6}{ }^{56}$ as the best-performed model at all the sub-regions and EMC among ten empirical models for calculating ETo with $\mathrm{R}^{2}$ values ranged from 0.87 to 0.99 . Shiri ${ }^{5}$ showed Priestley-Taylor outweighed the other 6 empirical models for estimating ETo with $\mathrm{R}^{2}$ values ranged from 0.636 to 0.792 . Mohawesh ${ }^{38}$ found Penman as the best-performed model in different regions of Jordan for estimating $\mathrm{ET}_{\mathrm{o}, \mathrm{s}}$ with $\mathrm{R}^{2}$ values ranged from 0.66 to $0.78^{74}$. Similarly, the mass-transfer-based model was the optimal model in computing ETo compared to the other models in humid regions in $\operatorname{Iran}^{40}$ and forest regions in Greece ${ }^{32}$. Based on the accuracy, reliability, simplicity and higher correlation with $\mathrm{ET}_{\mathrm{o}, \mathrm{s}}$, the most suitable method for ETo calculation in Bangladesh is $\mathrm{ET}_{\mathrm{o}, 6}$ model.

\section{Conclusions}

In this study, daily meteorological datasets from 20 weather stations from seven sub-regions in Bangladesh for the period of 1980-2017 were used. A widespread comparison between $\mathrm{ET}_{\mathrm{o}, \mathrm{s}}$ (calculated by FAO56-PM) and $\mathrm{ET}_{\mathrm{o}, \mathrm{i}}$ (calculated by HS, HM1, HM2, BT, WMO, ABT, IR1, IR2, MAK, PT, JH, TAB, TR, respectively) has been carried out. The possible roles of these 13 empirical models against the FAO56-PM were also explored in this study. Out of 20 stations, 5 stations showed an increasing trend of $\mathrm{ET}_{\mathrm{o}, \mathrm{s}} ; 11$ stations showed a decreasing trend and 4 stations showed no trend of $\mathrm{ET}_{\mathrm{o}, \mathrm{s}}$. Spatiotemporal distribution of $\mathrm{ET}_{\mathrm{o}, \mathrm{s}}$, and $\mathrm{ET}_{\mathrm{o}, \mathrm{i}}$ revealed that the model proposed by Abtew model showing the closest distribution of $\mathrm{ET}_{\mathrm{o}, \mathrm{i}}$ to $\mathrm{ET}_{\mathrm{o}, \mathrm{s}}$. RE, RMSE, MAE, MBE, and NSE were employed for evaluating the empirical models which were identified $\mathrm{ET}_{0,6}$ as the outperformed model with the lowest errors for calculating ETo in different sub-regions and whole Bangladesh. By contrast, $\mathrm{ET}_{0,5}$ (WMO) and $\mathrm{ET}_{0,13}$ (Turc) models selected as the poorer alternative models with the higher statistical errors. RF model also confirmed the Abtew as the outperformed model. The linear regression model showed that a strong linear correlation was found between FAO56-PM and Abtew model. Validation by using Eq. (33) explored the similar outcomes that the $\mathrm{ET}_{\mathrm{o}, 6}$ model outperformed than the other models. This study recommends the model proposed by the Abtew $\left(\mathrm{ET}_{\mathrm{o}, 6}\right)$ as the best alternative model with high accuracy, reliability and lowest errors for all the subregions and whole Bangladesh for calculating ETo when full climatic datasets for FAO56-PM model are unavailable. Future study should be focused on the evaluation of machine learning ensemble models for estimating daily ETo in Bangladesh. This research is a vital scientific contribution to ETo quantification and influential empirical models in Bangladesh where the large set of meteorological datasets could not be acquired. This study provides an important guidance for agricultural water practices, hydrological processes and irrigation management in Bangladesh, also useful as well as the similar subtropical climate region elsewhere in the world. 


\section{Data availability}

The datasets investigated in the present research are easily reached from the corresponding author on request.

Received: 22 February 2020; Accepted: 28 October 2020

Published online: 19 November 2020

\section{References}

1. Allen, R. G., Pereira, L. S., Raes, D. \& Smith, M. Crop Evapotranspiration-Guidelines for Computing Crop Water Requirements, FAO Irrigation and Drainge Paper, 56, FAO, pp. 1-326 (1998).

2. McMahon, T. A., Peel, M. C., Lowe, L., Srikanthan, R. \& McVicar, T. R. Estimating actual, potential, reference crop and pan evaporation using standard meteorological data: A pragmatic synthesis. Hydrol. Earth Syst. Sci. 17(4), 1331-1363 (2013).

3. Liu, X. et al. Comparison of 16 models for reference crop evapotranspiration against weighing lysimeter measurement. Agric. Water Manag. 184, 145-155 (2017).

4. Islam, A. T., Shen, S., Yang, S., Hu, Z. \& Chu, R. Assessing recent impacts of climate change on design water requirement of Boro rice season in Bangladesh. Theor. Appl. Climatol. https://doi.org/10.1007/s00704-019-02818-8 (2019).

5. Shiri, J. Modeling reference evapotranspiration in island environments: Assessing the practical implications. J. Hydrol. 570, 265-280 (2019).

6. Vangelis, H., Spiliotis, M. \& Tsakiris, G. Drought severity assessment based on bivariate probability analysis. Water ResourManag. 25, 357-371 (2010).

7. Vicente-Serrano, S. M., Beguería, S. \& López-Moreno, J. I. A multiscalar drought index sensitive to global warming: The standardized precipitation evapotranspiration index. J. Clim. 23(7), 1696-1718 (2010).

8. Gocic, M. \& Trajkovic, S. Drought characterisation based on water surplus variability index. Water Resour. Manage 28, 3179-3191. https://doi.org/10.1007/s11269-014-0665-4 (2014).

9. Penman, H. L. Natural evaporation from open water, bare soil and grass. Proc. R. Soc. Lond. Series Math. Phys. Sci. 193(1032), 120-145 (1948).

10. Xiang, K., Li, Y., Horton, R. \& Feng, H. Similarity and difference of potential evapotranspiration and reference crop evapotranspiration-A review. Agric. Water Manag. 232, 106043 (2020).

11. Peng, L., Li, Y. \& Feng, H. The best alternative for estimating reference crop evapotranspiration inifferent sub-regions of mainland China. Sci. Rep. 7(1), 5458. https://doi.org/10.1038/s41598-017-05660-y (2017).

12. Hargreaves, G. H. \& Samani, Z. A. Estimating potential evapotranspiration. J. Irrig. Drainage Division 108(3), 225-230 (1982).

13. Hargreaves, G. H. \& Samani, Z. A. Reference crop evapotranspiration from temperature. Appl. Eng. Agric. 1(2), 96-99 (1985).

14. Mojid, M. A., Rannu, R. P. \& Karim, N. N. Climate change impacts on reference crop evapotranspiration in North-West hydrological region of Bangladesh. Int. J. Climatol. 35(13), 4041-4046 (2015).

15. Rahman, M. A., Yunsheng, L., Sultana, N. \& Ongoma, V. Analysis of reference evapotranspiration (ETo) trends under climate change in Bangladesh using observed and CMIP5 data sets. Meteorol. Atmos. Phys. 131(3), 639-655 (2019).

16. Pham, M. T., Vernieuwe, H., De Baets, B. \& Verhoest, N. A coupled stochastic rainfall-evapotranspiration model for hydrological impact analysis. Hydrol. Earth Syst. Sci. 22(2), 1263-1283 (2018).

17. Ismail, S. M. \& El-Nakhlawy, F. S. Measuring crop water requirement and crop coefficient for blue panic crop under arid conditions using draining lysimeters. Irrig. Drainage 67(3), 454-460 (2018).

18. Samuel, A., Girma, A., Zenebe, A. \& Ghebreyohannes, T. Spatio-temporal variability of evapotranspiration and crop water requirement from space. J. Hydrol. 567, 732-742 (2018).

19. Wu, D. et al. Spatial-temporal variation in irrigation water requirement for the winter wheat-summer maize rotation system since the 1980s on the North China Plain. Agric. Water Manag. 214, 78-86 (2019).

20. Islam, A. R. M. T., Shen, S. \& Yang, S. Predicting design water requirementofwinterpaddyunderclimatechangeconditionusingfrequency analysis in Bangladesh. Agric. Water Manag. 195, 58-70. https://doi.org/10.1016/j.agwat.2017.10.003037 (2018).

21. Srivastava, R. K., Panda, R. K., Chakraborty, A. \& Halder, D. Comparison of actual evapotranspiration of irrigated maize in a sub-humid region using four different canopy resistance based approaches. Agric. Water Manag. 202, 156-165 (2018).

22. Lin, P. et al. Impacts of climate change on reference evapotranspiration in the Qilian Mountains of China: Historical trends and projected changes. Int. J. Climatol. 38(7), 2980-2993 (2018).

23. Paredes, P. \& Pereira, L. S. Computing FAO56 reference grass evapotranspiration PM-ETo from temperature with focus on solar radiation. Agric. Water Manag. 215, 86-102 (2019).

24. Li, M., Chu, R., Islam, A. R. M. \& Shen, S. Reference evapotranspiration variation analysis and its approaches evaluation of 13 empirical models in sub-humid and humid regions: A case study of the Huai river basin, eastern China. Water 10(4), 493 (2018).

25. Salam, R. \& Islam, A. R. M. T. Potential of RT, Bagging and RS ensemble learning algorithms for reference evapotranspiration prediction using climatic data-limited humid region in Bangladesh. J. Hydrol. https://doi.org/10.1016/j.jhydrol.2020.125241 (2020).

26. Pereira, L. S., Allen, R. G., Smith, M. \& Raes, D. Crop evapotranspiration estimation with FAO56: Past and future. Agric. Water Manag. 147, 4-20 (2015).

27. Droogers, P. \& Allen, R. G. Estimating reference evapotranspiration under inaccurate data conditions. Irrig. Drain. Syst. 16, 33-45 (2002).

28. Mendicino, G. \& Senatore, A. Regionalization of the Hargreaves coefficient for the assessment of distributed reference evapotranspiration in southern Italy. J. Irrig. Drain. 139(5), 349-362. https://doi.org/10.1061/(ASCE)IR.1943-4774.0000547 (2013)

29. Farzanpour, H., Shiri, J., Sadraddini, A. A. \& Trajkovic, S. Global comparison of 20 reference evapotranspiration equations in a semi-arid region of Iran. Hydrol. Res. 50(1), 282-300 (2019).

30. World Meteorological Organization (WMO). Measurement and Estimation of Evaporation and Evapotranspiration; Technical Paper (CIMO-Rep) Vol. 83 (WMO, Geneva, 1966).

31. Yeh, H.F. Comparison of evapotranspiration methods under limited data, current perspective to predict actual evapotranspiration, Daniel Bucur, IntechOpen. https://doi.org/10.5772/intechopen.68495(2017).

32. Bourletsikas, A., Argyrokastritis, I. \& Proutsos, N. Comparative evaluation of 24 reference evapotranspiration equations applied on an evergreen-broadleaved forest. Hydrol. Res. 49(4), 1028-1041 (2018).

33. Djaman, K. et al. Evaluation of the Penman-Monteith and other 34 reference evapotranspiration equations under limited data in a semiarid dry climate. Theoret. Appl. Climatol. 137(1-2), 729-743 (2019).

34. Muhammad, M. K. I. et al. Evaluation of empirical reference evapotranspiration models using compromise programming: A case study of Peninsular Malaysia. Sustainability 11(16), 4267 (2019).

35. Xystrakis, F. \& Matzarakis, A. Evaluation of 13 empirical reference potential evapotranspiration equations on the island of Crete in southern Greece. J. Irrig. Drainage Eng. 137(4), 211-222 (2011).

36. Chu, R. et al. Changes in reference evapotranspiration and its contributing factors in Jiangsu, a major economic and agricultural province of eastern China. Water 9(7), 486. https://doi.org/10.3390/w9070486 (2017).

37. Trajkovic, S. \& Kolakovic, S. Comparison of simplified pan-based equations for estimating reference evapotranspiration. J. Irrig. Drain Eng. 136(2), 137-140 (2010) 
38. Mohawesh, O. E. Evaluation of evapotranspiration models for estimating daily reference evapotranspiration in arid and semiarid environments. Plant Soil Environ. 57(4), 145-152 (2011).

39. Yao, T., Lu, H., Feng, W. \& Yu, Q. Evaporation abrupt changes in the Qinghai-Tibet plateau during the last half-century. Sci. Rep. 9, 20181. https://doi.org/10.1038/s41598-019-56464-1 (2019).

40. Tabari, H., Grismer, M. E. \& Trajkovic, S. Comparative analysis of 31 reference evapotranspiration methods under humid conditions. Irrig. Sci. 31(2), 107-117. https://doi.org/10.1007/s00271-011-0295-z (2013).

41. Almorox, J., Quej, V. H. \& Martí, P. Global performance ranking of temperature-based approaches for evapotranspiration estimation considering Köppen climate classes. J. Hydrol. 528, 514-522 (2015).

42. Shamshirband, S. et al. Estimation of reference evapotranspiration using neural networks and cuckoo search algorithm. J. Irrig. Drain Eng. https://doi.org/10.1061/(asce)ir.1943-4774.0000949 (2016).

43. Quej, V. H., Almorox, J., Arnaldo, J. A. \& Moratiel, R. Evaluation of temperature-based methods for the estimation of reference evapotranspiration in the Yucatán peninsula, Mexico. J. Hydrol. Eng. 24(2), 05018029 (2019).

44. Krishna, A. P. Selection of the Best Method of ET o Estimation Other Than Penman-Monteith and Their Application for the Humid Subtropical Region. Agricultural Research 4(2), 215-219 (2015).

45. Pandey, P. \& Pandey, V. Evaluation of temperature-based Penman-Monteith (TPM) model under the humid environment. Model. Earth Syst. Environ 2(3), 152. https://doi.org/10.1007/s40808-016-0204-9 (2016).

46. Rahman, M. S. \& Islam, A. R. M. T. Are precipitation concentration and intensity changing in Bangladesh overtimes? Analysis of the possible causes of changes in precipitation systems. Sci. Total Environ. 690, 370-387 (2019).

47. Kisi, O.\&Alizamir, M. Modelling reference evapotranspiration using a new wavelet conjunction heuristic method: wavelet extreme learning machine vs wavelet neural networks. Agric. For. Meteorol., 263, 41-48. https://doi.org/10.1016/j.agrformet. 2018.08.007 (2018).

48. Banglapedia. National Encyclopedia of Bangladesh. Asiatic Society of Bangladesh, Dhaka(2014).

49. Islam, A. R. M., Shen, S., Hu, Z., \& Rahman, M. A. Drought hazard evaluation in boro paddy cultivated areas of western Bangladesh at current and future climate change conditions. Advances in Meteorology. https://doi.org/10.1155/2017/3514381(2017).

50. Islam, A. R. M. T., Rahman, M. S., Khatun, R. \& Hu, Z. Spatiotemporal trends in the frequency of daily rainfall in Bangladesh during 1975-2017. Theoret. Appl. Climatol. https://doi.org/10.1007/s00704-020-03244-x (2020).

51. Abtew, W. Evapotranspiration measurements and modeling for three wetland systems in South Florida 1. JAWRA Journal of the American Water Resources Association 32(3), 465-473 (1996).

52. Jensen, M. E., \&Haise, H. R. Estimating evapotranspiration from solar radiation. Proceedings of the American Society of Civil Engineers, Journal of the Irrigation and Drainage Division, 89, 15-41(1963).

53. Irmak, S., Irmak, A., Allen, R. G. \& Jones, J. W. Solar and net radiation-based equations to estimate reference evapotranspiration in humid climates. Journal of irrigation and drainage engineering 129(5), 336-347 (2003).

54. Makkink, G. F. Testing the Penman formula by means of lysimeters. Journal of the Institution of Water Engineerrs 11, 277-288 (1957).

55. Priestley, C. H. B. \& Taylor, R. J. On the assessment of surface heat flux and evaporation using large-scale parameters. Mon. Weather Rev. 100(2), 81-92 (1972).

56. Berti, A., Tardivo, G., Chiaudani, A., Rech, F., \&Borin, M. Assessing reference evapotranspiration by the Hargreaves method in north-eastern Italy. Agricultural Water Management, 140, 20-25. https://doi.org/10.1016/j.agwat.2014.03.015(2014).

57. Turc, L. Estimation of irrigation water requirements, potential evapotranspiration: a simple climatic formula evolved up to date.Annals of Agronomy, 12,13-49 (1961).

58. Kato, T. Prediction of photovoltaic power generation output and network operation. In Integration of Distributed Energy Resources in Power Systems. Academic Press, 77-108 (2016).

59. Nash, J. E. \& Sutcliffe, J. V. River flow forecasting through conceptual models part I-A discussion of principles. J. Hydrol. 10(3), $282-290$ (1970).

60. Praveen, B. et al. Analyzing trend and forecasting of rainfall changes in India using non-parametrical and machine learning approaches. Sci. Rep. 10, 10342. https://doi.org/10.1038/s41598-020-67228-7 (2020).

61. Yue, S. \& Wang, C. The Mann-Kendall test modified by effective sample size to detect trend in serially correlated hydrological series. Water Resour. Manage 18(3), 201-218 (2004).

62. Mann, H. B. Nonparametric tests against trend. Econometr. J. Econ. Soc. https://doi.org/10.2307/1907187 (1945).

63. Kendall, M. G. Rank Correlation Methods 2nd edn. (Hafner Publishing Co, New York, 1955).

64. Rahman, M. A., Yunsheng, L. \& Sultana, N. Analysis and prediction of rainfall trends over Bangladesh using Mann-Kendall, Spearman's rho tests and ARIMA model. Meteorol. Atmos. Phys. https://doi.org/10.1007/s00703-016-0479-4 (2016).

65. Bayley, G. V. \& Hammersley, J. M. The "effective" number of independent observations in an autocorrelated time series. Suppl. J. R. Stat. Soc. 8(2), 184-197 (1946).

66. Sen, P. Estimates of the regression coefficient based on Kendall's tau. J. Am. Stat. Assoc. 63, 1379-1389 (1968).

67. Breiman, L. Random forests. Mach. Learn. 45(1), 5-32. https://doi.org/10.1023/A:1010933404324 (2001).

68. Strobl, C., Boulesteix, A. L., Zeileis, A. \& Hothorn, T. Bias in random forest variable importance measures: Illustrations, sources and a solution. BMC Bioinform. 8(1), 25 (2007).

69. Wang, Z. et al. Flood hazard risk assessment model based on random forest. J. Hydrol. 527, 1130-1141 (2015).

70. Díaz-Uriarte, R. \& De Andres, S. A. Gene selection and classification of microarray data using random forest. BMC Bioinform. $7(1), 3(2006)$.

71. Zheng, Y., He, Y. \& Chen, X. Spatiotemporal pattern of precipitation concentration and its possible causes in the Pearl River basin, China. J. Cleaner Prod. 161, 1020-1031 (2017).

72. Wang, S., Lian, J., Peng, Y., Hu, B. \& Chen, H. Generalized reference evapotranspiration models with limited climatic data based on random forest and gene expression programming in Guangxi, China. Agric. Water Manag. 221, 220-230 (2019).

73. Arellano, M. G. \& Irmak, S. Reference (potential) evapotranspiration. I: Comparison of temperature, radiation, and combinationbased energy balance equations in humid, subhumid, arid, semiarid, and Mediterranean-type climates. J. Irrig. Drainage Eng. 142(4), 04015065 (2016).

74. Jensen, D. T., Hargreaves, G. H., Temesgen, B. \& Allen, R. G. Computation of ETo under nonideal conditions. J. Irrig. Drain. Eng. 123(5), 394-400 (1997).

\section{Acknowledgements}

The authors are grateful to the authority of the Department of Disaster Management, Begum Rokeya University (BRUR), and Bangladesh Meteorological Department (BMD), Dhaka, Bangladesh for providing data facilities and others logistic support during the research period. 


\section{Author contributions}

R.S., A.R.M.T.I., and Q.B.P. designed, organized and wrote the paper. Q.B.P., M.D., and N.T.T.L. assisted in analyzing and processing the data. Q.B.P., M.D, N.T.T.L. and N.A. help to investigate the results. Q.B.P.: supervision. All authors revised the manuscript cautiously.

\section{Competing interests}

The authors declare no competing interests.

\section{Additional information}

Supplementary information is available for this paper at https://doi.org/10.1038/s41598-020-77183-y.

Correspondence and requests for materials should be addressed to N.T.T.L.

Reprints and permissions information is available at www.nature.com/reprints.

Publisher's note Springer Nature remains neutral with regard to jurisdictional claims in published maps and institutional affiliations.

(c) (i) Open Access This article is licensed under a Creative Commons Attribution 4.0 International License, which permits use, sharing, adaptation, distribution and reproduction in any medium or format, as long as you give appropriate credit to the original author(s) and the source, provide a link to the Creative Commons licence, and indicate if changes were made. The images or other third party material in this article are included in the article's Creative Commons licence, unless indicated otherwise in a credit line to the material. If material is not included in the article's Creative Commons licence and your intended use is not permitted by statutory regulation or exceeds the permitted use, you will need to obtain permission directly from the copyright holder. To view a copy of this licence, visit http://creativecommons.org/licenses/by/4.0/.

(c) The Author(s) 2020 